Pradeepika Gadai ${ }^{1}$

Kurukshetra University,

University School of Management,

Kurukshetra, Haryana (India)
316.62:[616.98:578.834(540)"2020"

Original scientific paper

Submitted 22/06/2020

Accepted 30/08/2020

doi: 10.5937/socpreg54-27205

\title{
BEHAVIOURAL INSIGHTS AND COVID-19 PANDEMIC IN INDIA
}

Abstract: The emergence of the novel COVID-19 has made pandemic preparedness a crucial issue for public health worldwide. A little is known about people behaviour in a pandemic situation. Such knowledge is however critical. Understanding the associated psychological and behavioural responses is vital for future intervention development. During the period of Lockdown Stage, from $25^{\text {th }}$ March to $14^{\text {th }}$ April 2020 in India, a survey was conducted among 700 people in Delhi NCR and Haryana state, to explore changes in their psychological and behavioural responses to the COVID-19 virus epidemic based on Protection Motivation Theory (PMT) which distinguishes two phases, namely a threat appraisal and a coping appraisal is applied . Further infected people should be isolated to minimize the spread of pandemic diseases. Therefore, the factors related to self-isolation (SI) should not be neglected, and it is important to investigate the factors leading the infected (or possibly infected) people to choose to self-isolate. For this purpose, the theory of planned behaviour (TPB) is used for providing conceptual framework for SI when facing a pandemic risk and a regression method is applied to investigate how attitude (ATT), subjective norms (SN), and perceived behavioural control (PBC) influence SI when facing a pandemic emergency. The results of this study provide relevant information that promotes theoretical understanding of psychological and behavioural intentions of people and enables us to shape future intervention development.

Keywords: COVID-19, pandemic risk, self-isolation, protection motivation theory (PMT), theory of planned behaviour (TBP) and behavioural responses

\section{Introduction}

COVID-19 pandemic is the worst situation face by this generation which stopped their fast forward life all of the sudden. Therefore people must prepare themselves for the inevitable COVID-19 pandemic. Apart from pharmaceutical contributions, non-pharmaceutical interventions (NPIs) are playing a significant role in preventing corona virus in all over the world because pandemic vaccine is not in place till now. NPIs include isolation; closing schools, marketplaces, offices, closing of borders; require hygiene measures, and so on.

\footnotetext{
1 Pradeepika.gadai@gmail.com
} 
By studying the behaviour of the people we can out find out the behavioural improvements which in turns can help in reducing the transmission of infection. World Health Organization put out a straightforward statement that behavioural insights are valuable to inform the planning of pandemic response measures. WHO's long years of experience had taught it that the containment of epidemics, particularly when a vaccine or treatment is months or years away, is as much behavioural as medical.(Source: Behavioural Insights, the WHO and COVID-19, $21^{\text {st }}$ May 2020)

On 11rh March 2020, the World Health Organization (WHO) declared the novel coronavirus (COVID-19) outbreak of a global pandemic. Its director said that WHO was "deeply concerned both by the alarming levels of spread and severity and by the alarming levels of inaction", inviting countries to take immediate action to contain the virus. "We should double down," he said. "We should be more aggressive." So India announced Lockdown Stage 1 from March 25th to 14th April 2020. According to WHO's April $14^{\text {th }}$ 2020 updates, globally there were 1.776 .867 confirmed cases and 111.828 deaths and now 7.136.744 confirmed cases and 407.068 deaths till $8^{\text {th }}$ June 2020. India was no exception according to the union health ministry there were 10.440 confirmed cases and death toll at 358 till last day of Lockdown 1.0 and now 260.093 confirmed cases and death toll at 7263 till $8^{\text {th }}$ June 2020 in Unlock period 1.0. Assuming the seriousness of the condition in the highly populated country like India and lack of vaccine of COVID-19, it becomes important to know about how Indian people are likely to react to a pandemic emergency during the period of lockdown 1.0. This paper disclosed the factors associated with psychological and behaviour responses of people in India during lockdown period 1.0 and observed research findings will apply in practice for the safety of society during pandemic.

\section{Theoretical Background}

There are several theories related to behavioural patterns specifically on risk perception of society in pandemic mentioned in literature. Among all these theories, Protection Motivation theory (PMT) developed by Rogers in 1975 is used to study the behavioural response of people in India. The PMT has two phases; the first is a threat appraisal and the second is a coping appraisal. Basically, the threat appraisal is to determine the belief about the likelihood of getting a disease or condition and perceived severity of the threat. The coping appraisal is to determined perceived response efficacy (protective behaviour response). According to the PMT, the threat appraisal stimulates the intention to act while the coping appraisal determines the action used. The action may be adaptive and lead to performing the advised protective or precautionary behaviours or it can be maladaptive thus leading to performing behaviours other than those advised (Kok, G., Jonkers, R., Gelissen, R. et al., 2010). Further it is advisable to self-isolate themselves if infected or probabilities to be infected to minimize the transmission of infection. Therefore, the factors that affect willingness to self- isolation (SI) should be considered. For this purpose, the theory of planned behaviour (TPB) is used. (Zhang et al., 2019). According to TPB that individual influenced by three factors: Attitude towards behaviour (ATT), Subjective norms (SN) and perceived behavioural control (PBC) (Figure 1.

Attitude in self-isolation can have a positive or negative influence. Subjective norms state the perceived social pressure to perform behaviour or not, so the perceived social norms related to their risk taking behaviour. $\mathrm{PBC}$ refers to the perceived ease or difficulty 
of performing the behaviour. It found that PBC influences the actual behaviour and intention. Therefore, the prime purpose of this study to explore the behavioural and psychological responses of the society in Indian context PMT and TPB used

\section{Research Question}

The aim of the study was to determine how people intend to behave in social as well psychological manner during the Lockdown Stage 1 period (25 ${ }^{\text {th }}$ March to 14th April 2020) in India because of the large scale COVID-19 pandemic.

\section{Methods and material}

The present descriptive cross-sectional study based on PMT and TPB concepts suggested in the literature conducted among 700 people in Delhi NCR and Haryana state during the lockdown 1.0 period. Participants asked about hygiene behaviour, better cough etiquette and face mask use, maladaptive and adaptive behaviour as social distancing behaviour, Perceived Trustworthiness of information sources and their willingness to self-isolate during pandemic risk through e- questionnaire randomly distributed.

\section{Data Analysis \\ Respondents' Profile}

Table 1 shows personal demographic characteristics of the sample of 700 people of gender, age, educational qualification including their self-rated health status and stress level.

\section{Threat Appraisal}

Table 2 shows the threat appraisal responses of the participants. Male and female participants equally worried more than normal to have COVID-19 but have a low anxiety/stress level. All levels of age groups were equally worried more than normal to have COVID-19 excluding the age group of 45-54 that was much less worried than normal and all age groups have anxiety/stress at a low level. Below-graduate participants were extremely worried to have COVID-19 but showed a low level of anxiety/stress. Graduate and post-graduate participants equally worried more than normal to have COVID-19 and their anxiety/stress level was low, The participants having a doctorate degree were also much less worried than normal with a low anxiety/stress level.

\section{Coping appraisal}

The factors affecting the use of preventive measures which include 8 hygiene factors, cough etiquette and face mask use measured coping appraisal.

\section{Factors affecting Hygiene behaviour}

Table 3 shows the association of 8 hygiene factors including measures relating to hand washing and home disinfection with personal demographic variables including their selfrated health and stress level by using multivariable logistic regression analyses in SPSS. 
Male age groups 25-34 and 45-54 were more associated with the use of hygiene measures. However, all age groups, not at all worried, less worried than normal and high-stress level ones, were found to be negatively associated with the frequency of cleaning or disinfecting house. Poor and fair health status was found significantly associated the lower use of hygiene measures but significantly positively associated with the frequency of cleaning or disinfecting house. Lower stress was not at all significantly associated with any hygiene measures, but medium and higher stress was found significantly associated with hygiene measures. Less worried and more worried than normal were significantly associated with the more intense use of hygiene measures. COVID-19 could spread by droplets, which is significantly associated with higher use of hygiene measures and cleaning or disinfecting the house.

Factors Affecting Better Cough Etiquette and Face Mask Use

Table 4 shows the factors associated with use of cough etiquette and face masks by using multivariable logistic regression analyses in SPSS. Males were found to be less covered mouth while sneezing or coughing compared to a reference group of females. Age groups 34-44 and 45-54 were significantly associated with covering their mouth while sneezing or coughing. Age groups 25-34, 35-44 and 45-54 used fewer face masks compared to the reference group of above 55. Graduates were significantly associated with covering their mouth while sneezing or coughing. Post-graduates, worried more than normal if infected, with a fair health status, were significantly associated with both. Those much less worried than normal if infected wear face mask less often compared to worried people. Medium anxiety/stress level, droplets and direct contact were significantly associated with covering the mouth while sneezing and coughing. Droplets and direct contact were also significantly associated with wearing face masks when outside.

\section{Maladaptive behaviour}

Approximately 55\% of all participants stated that the threat of the COVID-19 pandemic was exaggerated and medication for COVID-19 would become available soon and $67 \%$ participants agreed to accepted pandemic as reality. Almost $20 \%$ participants reported to feel powerless and wished not to have an infection. Despair (utter loss) and avoidance (stock up and stay indoors) were reported by almost $82 \%$ while only $18 \%$ agreed that it would not be as bad as predicted, which was wishful thinking. Almost 32\% believed that there was nothing they could do about it (See Figure2).

\section{Adaptive behaviour}

It shows the factors associated with 6 social distancing measures in Table 5 All age groups and education levels significantly associated with avoiding family function and gathering, but fair self - health status was relatively less avoiding family function. There was no significant association of avoiding family function with gender, stress/anxiety level and worried if infected. Male gender, all age groups, educated levels and self-rated health status associated with avoiding public transport and taxis. Higher and lower stress levels were also avoiding public transport. There was no significant association of avoiding religious places and going out to purchase items with any demographic factor apart from fair health 
status with avoiding religious places and poor self-rated heath status avoiding going out to purchase items. Only the age group of 18-24 significantly associated with avoiding going to workplaces, otherwise there was no significant association with all other demographic factors. The age group of 35-44 and lower level stress was more often going to workplaces. People who were much less worried than normal about getting infected were going out more often to purchase items compared to those worried if infected as a reference group. Male gender at all levels of education, fair self-rated health status and worried much more than normal, were significantly associated with maintaining social distancing while going out.

\section{Perceived trustworthiness of information sources}

Concerning the perceived trustworthiness of information sources, the participants considered health organizations (90.7\%) and government (77.9\%) most trustworthy. Print (50.6\%) and broadcast $(60.1 \%)$ media were reported as more trustworthy in comparison to social (15.4\%) media. Family and friends(28.9\%) was considered more trustworthy in comparison to the least trustworthy source of information, i.e. neighbours with only $7.4 \%$. (see Figure 3

\section{Perceived urgency of information}

Regarding the urgency of information, approximately 50\% participants wanted to receive information on protective measures urgently. Information on how to recognise an infection and wanting to know which places posed the greater risk was considered by $40 \%$ and $42 \%$ respectively. The ways of how the infection is transmitted, how it can be treated and severity of the infection were considered less urgent by $33 \%, 25 \%$ and $19.4 \%$ respectively. (see Figure 4

\section{Willingness to Self-Isolate When Facing a Pandemic Risk}

The factors affecting willingness to self-isolate following variables were studied based on TPB as described in Table 6 .

Hierarchical Linear Regression analysis was adopted to explore the effects of ATT, SN, and PBC on SI. First regression was done on SI as a dependent variable with the independent variable ATT as a benchmark model 1 . Then SN and PBC were added sequentially to the model and generated model 2 and model 3 respectively. Table 7 shows the model summary for the multiple regressions of changes in the willingness towards self-isolation when facing COVID-19 according to changes in ATT, SN and PBC. The adjusted R squared of the benchmark model 1 is lower than model 2 and model 3, which means that these models are more fitting than model 1.

Model 1 has R square value of 0.275 , which showed that the government mandatory isolation of infected people during a large-scale epidemic of an infectious disease scores interpretation for $27.5 \%$ of the variance in willingness to self-isolation. When SN scores added to Model 2, the value of R square increased to 0.388 (38.8\% of the variance in SI scores accounted for by 3 variables in the model 2). The R square change calculated the difference between $\mathrm{R}$ square of model 1 and model 2 . R square change was 0.113 which predicted that SN contributes only $11.3 \%$ to the additional variance in SI. When PBC scores were added to Model 3, the value of R square increased to 0.454 ( $45.4 \%$ of the variance in SI 
scores accounted for by 6 variables in model 3). The R square change in model 2 and model 3 was 0.066 which predicted that PBC contributes only $6.6 . \%$ the additional variance in SI. To find whether there is a statistically significant increase, Sig. F change $(\mathrm{p}<0.05)$ was used.

\section{Discussion}

Behavioural and psychological responses of the Indian society were mixed. Many participants reported worried more than normal to have COVID-19 but anxiety/stress level at lower side and mode of transmission is direct contact. Participants were less associated with frequency of house cleaning or disinfecting, or hand washing after sneezing, coughing or touching nose but they normally wash hands when come from outside and use soap for washing hands. The results also revealed that the participants were not used to washing hands after touching cash, hand drills, handles or door knobs. The study associated the mode of transmission through droplets with the use of hygiene measures and house cleaning or disinfecting. As far as cough etiquette and face mask use were concerned, it was reported that the participants had cough etiquette but did not use a face mask regularly.

Overall results predict that people still need to adopt more protective measures to save themselves from infection. Most participants have reported that they stock up and stay indoors, accepting the situation as reality, but they have hope that medications will be available soon. The participants adopted the social distancing behaviour by avoiding family functions, not using public transports and taxis but not avoiding going out to workplaces and to purchase items. The immediate information that participants wanted to receive was about protective measures, how to recognise the infection and which places posed the higher risk.

Self-isolation at home and quarantine are the most effective protective measures in today's pandemic situation. TPB provides a convenient conceptual framework for Self-isolation (SI) when facing pandemic risk. The results confirmed that attitude (ATT), subjective norms (SN) and perceived behavioural control (PBC) have a significant influence on willingness to self-isolate. The attitude towards self-isolation played an important role compared to SN and PBC, because of uncertainty in social acceptance of the people who recovered from COVID-19, but they would let others know if they were infected. Another reason was that the participants showed less confidence that they could protect themselves and family from the large-scale infectious disease.

\section{Conclusion}

In conclusion, this study verifies that it perceives COVID-19 as a genuine risk in a highly populated country like India. The lack of substantial changes in protective behaviour during the lockdown 1.0 requires proper information, extensive awareness programs and more promotion through trusted sources of information and strong action against fake information providing sources which turn out to be helpful in understanding pandemic and enhance the knowledge about protective measures. It has found that ignorance or lack of motivation or unavoidable economic consequences may be hard to change in habitual behaviour in terms of protective and social distancing behaviour which were required in a pandemic situation, despite the ongoing government promotion and media coverage. Based on the findings of this study, there are few implications that help in improving the habitual behaviour in COVID-19 and we should consider more substantial and integrated attempts. 
Прадепика Гадаи ${ }^{1}$

Универзитет Курукшетра, Факултет за менаџмент, Курукшетра, Харајана (Индија)

\title{
БИХЕВИОРАЛНИ УВИДИ И ПАНДЕМИЈА COVID-19 У ИНДИЈИ
}

\author{
(Превоg In Extenso)
}

Сажетак: Појава новог вируса COVID-19 је спремност за одговор на пандемију учинила кључним питањем у смислу јавног здравља у целом свету. Мало тога се зна о понашању људи у пандемијској ситуацији. Ипак, то понашање је од пресудног значаја. Разумевање повезаних психолошких и бихевиоралних одговора је од кључне важности за осмишљавање мера за сличне ситуације у будућности. У Индији је током карантина, тј. од 25. марта до 14. априла 2020, спроведено истраживање на 700 људи у главном граду Делхију и савезној држави Харајана, како би се испитале промене у психолошким и бихевиоралним одговорима на епидемију вируса COVID-19, а на основу теорије мотивације за заштиту (PMT), у којој се препознају и примењују две фазе, тачније, процена претње и начин ношења са претњом. Поред овога, заражене особе би требало да се изолују, како би се ширење пандемијских болести свело на најмању меру. Стога не треба занемарити факторе који се односе на самоизолацију (SI), а значајно је истражити и факторе који доводе до тога да заражене (или могуће заражене) особе одлуче да оду у самоизолацију. Теорија планираног понашања (ТВР) се у том циљу користи за формирање концептуалног оквира за SI, у ситуацијама суочавања са пандемијским ризиком, а регресиони метод се примењује да би се испитало како став (ATT), субјективне норме (SN) и перципирана контрола понашања (PBC) утичу на SI у околностима суочавања са ванредном ситуацијом у случају пандемије. Резултати студије пружају релевантне информације које доприносе теоријском разумевању психолошких и бихевиоралних намера људи, те нам омогућава да осмислимо мере за сличне ситуације у будућности.

Кључне речи: COVID-19, ризик од пандемије, самоизолација, теорија мотивације за заштиту (РМТ), теорија планираног понашања (ТВР) и бихевиорални одговори

1 Pradeepika.gadai@gmail.com 


\section{Увод}

Пандемија COVID-19 је најтежа ситуација са којом се ова генерација суочила, при чему је нагло заустављен њен динамични живот. Из тог разлога се људи морају припремити за неизбежну пандемију COVID-19. Поред доприноса који дају фармацеутске куће, нефармацеутске мере (NPI) такође имају значајну улогу у спречавању ширења коронавируса у целом свету, због тога што још не постоји вакцина. NPI обухватају изолацију; затварање школа, пијаца, канцеларија и граница; захтеване хигијенске мере итд. Проучавајући понашање људи можемо се упознати са бихевиоралним побољшањима, што, с друге стране, може помоћи смањењу преношења заразе. Светска здравствена организација (С3О) је недвосмислено изјавила да су бихевиорални увиди драгоцени јер пружају информације које ће омогућити планирање мера одговора на пандемију. Дугогодишње искуство СЗО научило нас је да је обуздавање епидемија, нарочито када ће до вакцине или излечења проћи месеци или године, подједнако медицинско и бихевиорално питање. (Извор: Behavioural Insights, the WHO and COVID-19, $21^{\text {st }}$ May 2020)

Светска здравствена организација је 11. марта 2020. објавила глобалну пандемију новог коронавируса (COVID-19). Директор C3О је рекао да је СЗО „дубоко забринута и због узнемирујућих нивоа ширења и тежине, као и због узнемирујућих нивоа неделања", па је позвао државе да без одлагања предузму активности за спречавање ширења вируса. „Требало би да се снажно обавежемо”, рекао је. „Требало би да будемо агресивнији”. Тако је Индија објавила карантин који је трајао од 25. марта до 14. априла 2020. године. Према информацијама СЗО од 14. априла 2020, у свету је било 1.776 .867 потврђених случајева, као и 111.828 преминулих, док је 8 . јуна 2020. број потврђених случајева износио 7.136.744, а број преминулих 407.068 смртних исхода. Ни Индија није била изузетак, те је према подацима Министарства здравља последњег дана карантина број потврђених случајева износио 10.440, уз 358 преминулих, док је до 8. јуна 2020., у време када карантин није био на снази, број потврђених случајева износио 260.093, а преминулих 7.263. Имајући у виду озбиљност ситуације у густо насељеној земљи попут Индије, као и непостојање вакцине против COVID-19, на значају добија чињеница да је потребно сазнати на који ће начин грађани Индије највероватније реаговати на избијање пандемије током карантина. У овом раду су описани фактори који су повезани са психолошким и бихевиоралним одговорима грађана Индије током карантина, а налази истраживања биће примењени у пракси ради безбедности друштва током пандемије.

\section{Теоријска позадина}

У литератури постоји неколико теорија које се односе на обрасце понашања, конкретно на друштвену перцепцију ризика током пандемије. Међу свим овим теоријама, теорија мотивације за заштиту (РМТ), коју је 1975. развио Роџерс (Rogers), употребљена је за проучавање бихевиоралног одговора грађана Индије. РМТ има две фазе, од којих је прва процена претње, а друга је процена начина ношења са претњом. У суштини, процена претње служи да се утврди до које мере се верује у могућност заразе или здравственог проблема, као и колика је перципирана озбиљност претње. 
Процена начина ношења са претњом треба да утврди перципирану ефикасност одговора (заштитни бихевиорални одговор). Према РМТ, процена претње поспешује намеру да се нешто предузме, док процена начина ношења са претњом треба да утврди које ће се активности спровести. Поступање може бити адаптивно и довести до препорученог начина заштитног или превентивног понашања, или неадаптивно, што резултира начинима понашања који се разликују од препоручених (Kok, G., Jonkers, R., Gelissen, R. et al., 2010). Поред тога, зараженим особама или особама код којих постоји вероватноћа заразе препоручује се самоизолација, како би се на најмању меру свело преношење заразе. Из овог разлога треба размотрити факторе који утичу на спремност на самоизолацију (SI). У ову сврху се примењује теорија планираног понашања (ТPB). (Zhang et al., 2019). Према ТРB, на заражену особу утичу три фактора: став према понашању (ATT), субјективне норме (SN) и перципирана контрола понашања (РВС) Слика 1).

Став у самоизолацији може имати позитиван или негативан утицај. Субјективне норме наглашавају перципирани друштвени притисак да се понашамо или не понашамо на одређени начин, тако да су перципиране друштвене норме повезане са ризичним видовима понашања. РВС се односи на перципирану лакоћу или тешкоћу понашања на одређени начин. Установљено је да РВС утиче на стварно понашање и намеру. Због тога је примарни циљ ове студије да истражи психолошке и бихевиоралне одговоре друштва у индијском контексту примењујући РМТ и ТРВ.

\section{Истраживачко питање}

Циљ студије био је да утврди каквом понашању су људи у Индији били склони, како у друштвеном тако и психолошком смислу, током карантина (од 25. марта до 14. априла) због пандемије COVID-19 великих размера.

\section{Методи и материјал}

Ова дескриптивна студија пресека заснована је на појмовима РМТ и ТРВ који су наведени у литератури. У студији је учешће узело 700 испитаника у главном граду Делхију и савезној држави Харајан током карантина. Испитаницима су путем насумично дистрибуираног електронског упитника постављена питања о понашању у смислу хигијене, строгом придржавању правила понашања приликом кашљања, употреби заштитних маски за лице, о неадаптивном и адаптивном понашању, као што је социјално дистанцирање, о перципираној поузданости извора информација и њиховој спремности на самоизолацију током постојања пандемијског ризика.

\section{Анализа података \\ Профил испитаника}

Табели 1 су приказане личне демографске карактеристике узорка од 700 људи, а састоје се од пола, старосне доби, степена образовања, укључујући и личну оцену здравственог стања и нивоа стреса. 


\section{Процена претње}

Табели 2 су приказани одговори испитаника на питања о процени претње. Испитаници и мушког и женског пола били су неуобичајено забринути да ће се заразити вирусом COVID-19, али им је ниво анксиозности/стреса био низак. Сви нивои старосних група, били су неуобичајено забринути да ће се заразити вирусом COVID-19, с изузетком испитаника из старосне групе 45-54 година, који су били много мање забринути, док су анксиозност и стрес код свих старосних група били на ниском нивоу. Испитаници са завршеном средњом школом били су изузетно забринути да су заражени вирусом COVID-19, али су показивали низак ниво анксиозности/ стреса. Испитаници са факултетском дипломом и магистри били су неуобичајено забринути да ће се заразити вирусом COVID-19, док је њихов ниво анксиозности/ стреса био низак. Такође, испитаници са титулом доктора наука били су много мање забринути и код њих је забележен низак ниво анксиозности/стреса.

\section{Процена ношења с претњом}

Фактори који утичу на примену мера превенције, којима је обухваћено 8 хигијенских фактора, правила понашања приликом кашљања и ношење заштитне маске, употребљени су за мерење процене ношења са претњом.

\section{Фактори који утичу на понашање у смислу хигијене}

Табели 3 је приказана повезаност 8 хигијенских фактора, где су, применом мултиваријабилних регресионих анализа кроз софтвер SPSS, мере прања руку и дезинфекције стамбеног простора доведене у везу са личним демографским варијаблама, укључујући личну оцену здравственог стања и нивоа стреса.

Код испитаника мушког пола из старосних група 25-34 и 45-54 година постоји већа повезаност са применом хигијенских мера. У свим старосним групама, било да нису нимало забринути, забринути мање него што је уобичајено и са високим нивоом стреса, присутна је негативна веза са учесталошћу чишћења или дезинфекције стамбеног простора. Код испитаника лошег или задовољавајућег здравственог стања значајна је веза са мање интензивном применом хигијенских мера, али постоји значајна позитивна веза са учесталошћу чишћења или дезинфекције стамбеног простора. Нижи ниво стреса уопште није значајно повезан са било којим хигијенским мерама, али се показало да су средњи и виши ниво стреса значајно повезани са хигијенским мерама. Код испитаника који су били мање и више забринути него што је уобичајено постоји значајна веза са интензивнијом применом хигијенских мера. Ширење вируса COVID-19 капљичним путем значајно је повезано са интензивнијом применом хигијенских мера и чишћењем или дезинфекцијом стамбеног простора.

Фактори који утичу на строже придржавање правила понашања приликом кашљања и употребу заштитне маске за лице

у Табели 4 су приказани фактори који су повезани са правилима понашања приликом кашљања и употребом заштитне маске, добијени применом мултиваријабилне регресионе анализе кроз софтвер SPSS. Показало се да испитаници мушког пола ређе 
покривају уста приликом кијања или кашљања у поређењу са референтном групом испитаника женског пола. Код старосних група 34-44 и 45-54 постоји значајна повезаност са покривањем уста приликом кијања или кашљања. Старосне групе 25-34, 35-44 и 45-54 година су мање користиле заштитне маске за лице у поређењу са референтном групом старости преко 55 година. Код испитаника са факултетском дипломом присутна је значајна веза са покривањем уста приликом кијања или кашљања. Испитаници-магистри били су неуобичајено забринути да ли су заражени, а код испитаника задовољавајућег здравственог стања постоји значајна повезаност са оба фактора. Испитаници који су били много мање него што је уобичајено забринути да ли су заражени ређе су носили заштитне маске у поређењу са испитаницима који су били забринути. Средњи ниво анксиозности/стреса, капљице и директан контакт значајно су повезани са покривањем уста приликом кијања и кашљања. Капљице и директан контакт такође су значајно повезани са ношењем заштитних маски на отвореном.

\section{Неадаптивно понашање}

Приближно 55\% свих испитаника сматрало је да је претња пандемије COVID-19 преувеличана, као и да ће лек против вируса COVID-19 ускоро постати доступан, док је $67 \%$ испитаника решило да пандемију прихвати као реалност. Скоро $20 \%$ испитаника казало је да се осећа беспомоћно и прижељкује да се не зарази. Очај (потпуна изгубљеност) и избегавање (гомилање намирница и неизлажење из куће) навело је скоро 82\% испитаника, уз само 18\% њих који прижељкују да неће све испасти тако лоше као што се очекивало. Скоро $32 \%$ испитаника је сматрало да се ништа не може учинити (видети Слику 2).

\section{Адаптивно понашање}

у Табели 5 су приказани фактори повезани са 6 мера социјалног дистанцирања. Код испитаника свих старосних група и степена образовања постоји значајна веза са избегавањем породичних славља и окупљања, мада су испитаници који су своје здравствено стање лично оценили као прихватљиво релативно мање избегавали одласке на породична славља. Није било значајне повезаности пола са избегавањем породичних славља, нивоом стреса/анксиозности и забринутошћу да ли су заражени. Код испитаника мушког пола, свих старосних група, степена образовања и личне оцене здравственог стања постоји веза са избегавањем јавног превоза и таксија. Испитаници са вишим и нижим нивоом стреса такође су избегавали да користе јавни превоз. Није постојала значајна повезаност избегавања одласка у верске објекте и у набавку намирница са било којим демографским фактором, осим код испитаника прихватљивог здравственог стања са избегавањем верских објеката, и лично оцењеног лошег здравственог стања са избегавањем одласка у набавку намирница. Само код старосне групе 18-24 постоји значајна веза са избегавањем одласка на радно место. Што се тиче осталог, није било значајне повезаности са осталим демографским факторима. Испитаници из старосне групе 35-44 и са нижим нивоом стреса чешће су одлазила на посао. Испитаници забринути много мање него што је уобичајено да су заражени чешће су излазили у набавку намирница у поређењу са 
референтном групом испитаника који су били забринути. Код испитаника мушког пола, свих степена образовања, са лично оцењеним прихватљивим здравственим стањем, и испитаника забринутих да су заражени више него што је уобичајено, постоји значајна веза са држањем социјалне дистанце на отвореном.

\section{Перципирана поузданост извора информација}

Што се тиче перципиране поузданости извора информација, испитаници су сматрали да су здравствене организације $(90,7 \%)$ и влада $(77,9 \%)$ најпоузданији. Штампани медији $(50,6 \%)$ и телевизија $(60,1 \%)$ су наведени као поузданији у поређењу са друштвеним мрежама $(15,4 \%)$. Породица и пријатељи $(28,9 \%)$ сматрају се поузданијима у поређењу са најмање поузданим извором информација, односно суседима, са само 7,4\% (видети Слику 3.

\section{Перципирана хитност у објављивању информација}

Када је реч о хитности у објављивању информација, приближно 50\% испитаника је желело да брже добија информације о заштитним мерама. 40\% испитаника је хитнима сматрало информације о томе како препознати инфекцију, а $42 \%$ о местима која представљају већи ризик. Информације о томе како се преноси инфекција, како се лечи и озбиљност инфекције су сматрала мање хитним за $33 \%, 25 \%$ односно 19,4\% (видети Слику 4 .

\section{Спремност на самоизолацију приликом суочавања са пандемијским ризиком}

Како би се проучили фактори који утичу на спремност на самоизолацију, на основу ТРВ су проучене следеће варијабле, што је приказано у Габели 6.

Хијерархијска линеарна регресиона анализа примењена је како би се испитали ефекти става (ATT), субјективних норми (SN) и перципиране контроле понашања (PBC) на самоизолацију (SI). Прво је рађена регресија на SI, као зависну варијаблу са независном варијаблом АТТ, као референтни модел 1. Моделу су затим секвенцијално додати SN и PBC, те су појединачно добијени модел 2 и модел 3. УТабели 7 је сажето приказан модел вишеструке регресије промена у спремности на самоизолацију приликом суочавања са вирусом COVID-19, у складу са променама ATT, SN и РВС. Прилагођена квадратна вредност R из референтног модела 1 је нижа него код модела 2 и модела 3, што значи да су ови модели подеснији него модел 1.

Квадратна вредност R у моделу 1 износи 0,275, што показује да мера обавезне самоизолације заражених особа коју је наложила влада током епидемије заразне болести великих размера може бити тумачење за 27,5\% варијансе спремности на самоизолацију. Када су вредности SN додате моделу 2, квадратна вредност R ce повећала на 0,388 (38,8\% варијансе вредности SI, што објашњавају 3 варијабле у моделу 2). Кроз промену квадратне вредности $\mathrm{R}$ израчуната је разлика између квадратне вредности R y моделу 1 и у моделу 2. Промена квадратне вредности R je износила 0,113, што значи да SN са само 11,3\% учествује у додатној варијанси SI. Када су вредности РВС додате моделу 3, квадратна вредност R се повећала на 0,454 (45,4\% 
варијансе вредности SI, што објашњавају 6 варијабли у моделу 3). Промена квадратне вредности R у моделу 2 и моделу 3 је износила 0,066, што значи да РВC са само 6,6\% учествује у додатној варијанси SI. Да би се утврдило постоји ли статистички значајно повећање, коришћена је Sig. промена F (p<0,05).

\section{Дискусија}

Бихевиорални и психолошки одговори индијског друштва били су разнолики. Многи испитаници су казали да су више него што је уобичајено забринути да имају COVID-19, али ниво стреса/анксиозности нагиње нижем, док је као начин трансмисије наведен директан контакт. Код испитаника је постојала мања повезаност са учесталошћу чишћења или дезинфекције стамбеног простора или прањем руку након кијања, кашљања или додиривања носа, али они и иначе перу руке када дођу споља и обавезно користе сапун. Резултати су такође показали да испитаници нису навикли да перу руке након додиривања новца, гелендера, ручки или квака. Резултати студије су повезали ширење инфекције капљичним путем са применом хигијенских мера и чишћењем или дезинфекцијом стамбеног простора. Када је реч о правилима понашања приликом кашљања и употреби заштитне маске, испитаници су казали да се придржавају правила понашања приликом кашљања, али да заштитну маску не носе редовно.

Целокупни резултати указују да људи тек треба да усвоје јаче мере заштите како би се сачували од инфекције. Испитаници су углавном навели да су купили довољно намирница и да нису излазили из куће. Такође су казали да су ситуацију прихватили као реалност, али и изразили наду да ће лек ускоро бити доступан. Испитаници су прихватили понашање социјалног дистанцирања тако што су избегавали породичне прославе, нису користили јавни превоз и такси, с тим што нису избегавали да иду на посао или у набавку. Непосредне информације који су испитаници желели да добију односиле су се на мере заштите, како да препознају инфекцију, те која места представљају већи ризик заражавања.

Самоизолација код куће и карантин су најефикасније мере заштите у данашњој пандемијској ситуацији. ТРВ пружа адекватан концептуални оквир за самоизолацију (SI) у ситуацијама када смо суочени са ризиком пандемије. Резултати су потврдили да став (ATT), субјективне норме (SN) и перципирана контрола понашања (РBC) имају значајан утицај на спремност на самоизолацију. Став према самоизолацији имао је важнију улогу у поређењу са SN и PBC, и то због несигурности у друштвено прихватање лица која су се опоравила од вируса COVID-19, али су друге обавестила о томе да су заражени. Још један разлог био је тај што су учесници изразили мању сигурност да могу заштитити себе и своју породицу од заразне болести великих размера.

\section{Закључак}

У закључку бисмо могли рећи да ова студија потврђује да се COVID-19 перципира као истински ризик у густо насељеној држави попут Индије. Због одсуства суштинских промена у понашању које ће омогућити заштиту током карантина, неопходно је имати ваљане информације, свеобухватне програме подизања свести и већу 
промоцију кроз поуздане изворе информација, као и снажну активност у борби против извора који објављују лажне вести, што ће бити од помоћи за разумевање пандемије и омогућити шире познавање мера заштите. Установљено је да би незнање или мањак мотивације или неизбежне последице на економију могле бити разлог за споре промене бихевиоралних навика, када је реч о заштитним мерама и социјалном дистанцирању, који су неопходни у пандемијској ситуацији, упркос континуираној промоцији коју спроводи влада и бављењу овим темама у медијима. На основу налаза ове студије може се закључити да постоји врло мало импликација које помажу бољим бихевиоралним навикама током пандемије COVID-19, те би требало размотрити додатне суштинске и интегрисане покушаје.

\section{REFERENCES / ЛИTЕPATУPA:}

Balinska, M., \& Rizzo, C. (2009). Behavioural responses to influenza pandemics: what do we know? PLoS currents, 1, RRN1037.https://doi.org/10.1371/currents.rrn1037

Benjamin J. Cowling et al. (2010). Community psychological and behavioural responses through the first wave of the 2009 influenza A(H1N1) pandemic in Hong Kong, The Journal of Infectious Diseases, Volume 202, Issue 6, Pages 867-876, https://doi. org/10.1086/655811

Flowers, P., Davis, M., Lohm, D., Waller, E., \& Stephenson, N. (2016). Understanding pandemic influenza behaviour: An exploratory biopsychosocial study. Journal of health psychology, 21(5), 759-769 https://doi.org/10.1177/1359105314537542

Kok, G., Jonkers, R., Gelissen, R. et al. (2010), Behavioural intentions in response to an influenza pandemic. BMC Public Health 10, 174.https://doi.org/10.1186/1471-245810-174

McVernon, J. et al. (2011). Recommendations for and compliance with social restrictions during implementation of school closures in the early phase of the influenza A (H1N1) 2009 outbreak in Melbourne, Australia. BMC infectious diseases, 11, 257. https://doi. org/10.1186/1471-2334-11-257

Meilicke, G., Riedmann, K., Biederbick, W., Müller, U., Wierer, T., \& Bartels, C. (2013). Hygiene perception changes during the influenza A H1N1 pandemic in Germany: incorporating the results of two cross-sectional telephone surveys 2008-2009. BMC Public Health 13, 959

Norman P, Boer H, Seydel ER (2005). Protection Motivation Theory. Predicting health behaviour. Edited by: Conner M, Norman P. 2005, Berkshire, UK: Open University Press, 81-126.

Yeung, N., Lau, J., Choi, K., \& Griffiths, S. (2017). Population Responses during the Pandemic Phase of the Influenza A(H1N1)pdm09 Epidemic, Hong Kong, China. Emerging Infectious Diseases, 23(5), 813-815 https://dx.doi.org/10.3201/ eid2305.160768.

Zhang, X., Wang, F., Zhu, C., \& Wang, Z. (2019). Willingness to Self-Isolate When Facing a Pandemic Risk: Model, Empirical Test, and Policy Recommendations. International journal of environmental research and public health, 17(1), 197. 


\section{ПРИЛОГ/AРРЕNDIX}

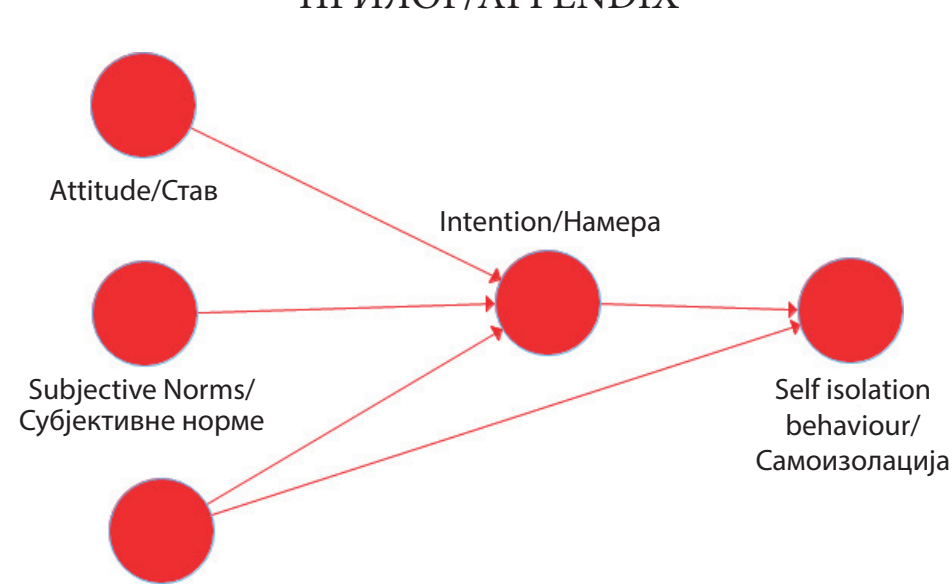

Percivied behaviorial control/

Перципирана бихевиорална контрола

Figure 1: TPB Model proposed by Icek Ajzen (1985): attitudes, subjective norms, perceived control towards behaviour. /

Слика 1: Модел ТРВ који сугерише Ицек Ајзен (1985) представљају: ставови, субјективне норме и перципирана контрола понашања.

Table 1: Demographic characteristics of the participants $(\mathrm{n}=700)$ /

Табела 1: Демографске карактеристике испитаника $(\mathrm{n}=700)$

\begin{tabular}{|c|c|c|c|}
\hline \multicolumn{2}{|r|}{$\begin{array}{l}\text { Characteristics/ } \\
\text { Карактеристике }\end{array}$} & $\begin{array}{c}\text { Frequency/ } \\
\text { Фреквенција }\end{array}$ & $\begin{array}{c}\text { Percentage/ } \\
\text { Проценат }\end{array}$ \\
\hline \multirow[t]{2}{*}{ Gender/Пол } & MALE/MУШКИ & 440 & 62,9 \\
\hline & FEMALE/ЖЕНСКИ & 260 & 37,1 \\
\hline \multirow[t]{5}{*}{ Age/Старост } & $18-24$ & 125 & 17,9 \\
\hline & $25-34$ & 235 & 33,6 \\
\hline & $35-44$ & 160 & 22,9 \\
\hline & $45-54$ & 52 & 7,4 \\
\hline & Above $55 /$ Преко 55 & 128 & 18,3 \\
\hline \multirow{4}{*}{$\begin{array}{c}\text { Education/Степен } \\
\text { образовања }\end{array}$} & Below Graduation/Средња школа & 48 & 6,9 \\
\hline & Graduation/Факултетска диплома & 126 & 18,0 \\
\hline & Post-Graduation/Магистар & 495 & 70,7 \\
\hline & Doctorate/Доктор наука & 31 & 4,4 \\
\hline \multirow{4}{*}{$\begin{array}{l}\text { Self-rated } \\
\text { Нealth Status/ } \\
\text { Лична оцена } \\
\text { здравственог } \\
\text { стања }\end{array}$} & Poor/Лоше & 34 & 4,9 \\
\hline & Fair/Прихватљиво & 71 & 10,1 \\
\hline & Good/Добро & 549 & 78,4 \\
\hline & Excellent/Одлично & 46 & 6,6 \\
\hline \multirow{4}{*}{$\begin{array}{l}\text { level of anxiety/ } \\
\text { stress/ниво } \\
\text { анксиозоности/ } \\
\text { стреса }\end{array}$} & High/Висок & 64 & 9,1 \\
\hline & Medium/Средњи & 279 & 39,9 \\
\hline & Low/Низак & 202 & 28,9 \\
\hline & No anxiety/stress/Без анксиозности/стреса & 155 & 22,1 \\
\hline
\end{tabular}




\begin{tabular}{|c|c|c|c|c|c|c|c|c|c|c|c|c|c|c|c|c|c|c|c|}
\hline & 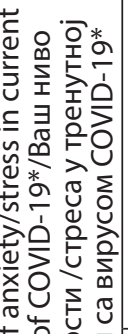 & 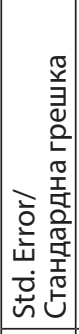 & ర্ত & & $\stackrel{8}{\circ}$ & ô. & & 응 & & $\begin{array}{l}1 \\
0 \\
0\end{array}$ & $\frac{n}{\sigma}$ & & $\begin{array}{l}8 \\
0 \\
0\end{array}$ & $\frac{n}{0}$ & $\begin{array}{l}\hat{0} \\
0 \\
0\end{array}$ & ¿ & & $\frac{\pi}{\square}$ & \\
\hline & 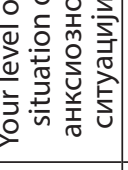 & 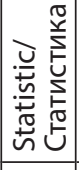 & $\stackrel{n}{\stackrel{n}{i}}$ & $\begin{array}{c}m \\
\sigma \\
\sigma\end{array}$ & 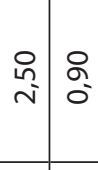 & 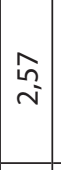 & $\begin{array}{l}\text { જે } \\
\delta\end{array}$ & $\begin{array}{l}8 \\
i \\
i\end{array}$ & $\stackrel{\text { ¿ }}{-}$ & 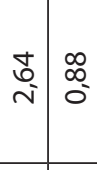 & $\begin{array}{c}\hat{\infty} \\
i\end{array}$ & $\stackrel{g}{\circ}$ & $\begin{array}{l}0 \\
i \\
N\end{array}$ & $\begin{array}{l}8 \\
m \\
m\end{array}$ & \begin{tabular}{l|l}
$\infty$ & \\
0 & 1 \\
$\sim$ & 1
\end{tabular} & \begin{tabular}{l|l}
$\stackrel{\infty}{n}$ \\
\\
$\tilde{o}$ & $\stackrel{n}{\sim}$
\end{tabular} & బิ & $\frac{0}{m}$ & $\frac{9}{0}$ \\
\hline 乙 & 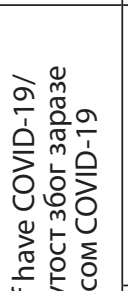 & 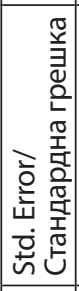 & J & & $\begin{array}{l}8 \\
0 \\
0\end{array}$ & $\begin{array}{l}\infty \\
0 \\
0 \\
0\end{array}$ & & ஜ: & & $\begin{array}{l}\hat{0} \\
0 \\
0\end{array}$ & $\frac{m}{\sigma}$ & & $\begin{array}{l}\infty \\
0 \\
0 \\
0\end{array}$ & : & $\begin{array}{l}8 \\
0\end{array}$ & O & & $\frac{n}{5}$ & \\
\hline & ) & 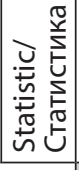 & i & $\begin{array}{l}m \\
\tilde{\sigma}\end{array}$ & 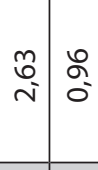 & $\stackrel{i n}{\sim}$ & $\begin{array}{l}\infty \\
\infty \\
0 \\
0\end{array}$ & 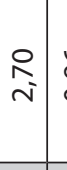 & $\begin{array}{l}\text { ̊̆ } \\
\vdots\end{array}$ & \begin{tabular}{l|l}
\multirow{\sim}{*}{} & $\bar{\sigma}$ \\
\multirow{\sigma}{*}{}
\end{tabular} & $\frac{a}{i}$ & $\begin{array}{l}m \\
\sigma \\
\sigma\end{array}$ & \begin{tabular}{l|l}
\multirow{2}{*}{} & $\infty$ \\
$\sim$ & $\infty$ \\
$\sim$ & 0
\end{tabular} & 8 & 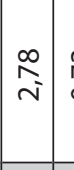 & 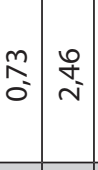 & న్ & $\frac{0}{i}$ & $\begin{array}{l}m \\
\infty \\
0 \\
0\end{array}$ \\
\hline & \multirow{3}{*}{\multicolumn{2}{|c|}{ 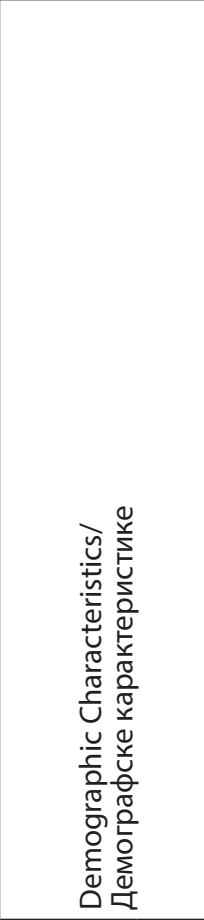 }} & 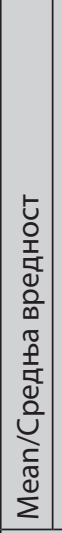 & 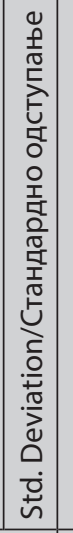 & 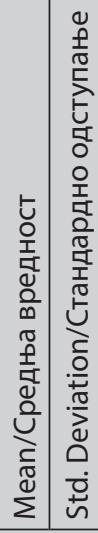 & 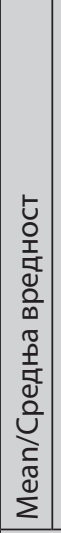 & 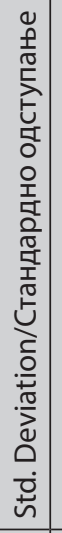 & 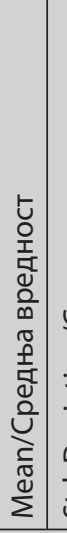 & 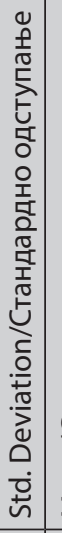 & 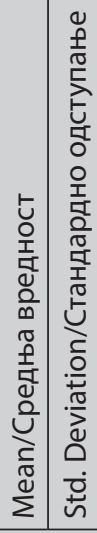 & 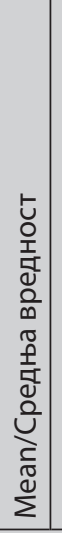 & 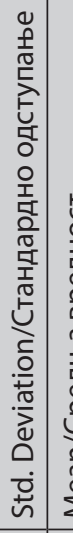 & 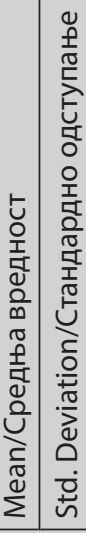 & 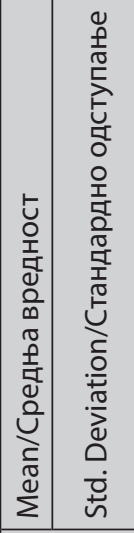 & 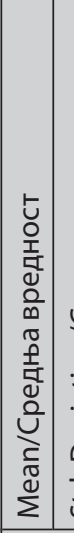 & 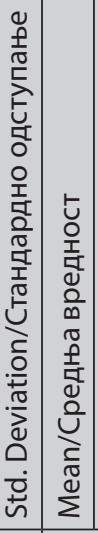 & 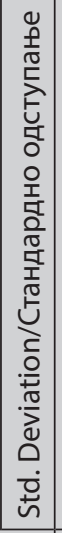 & 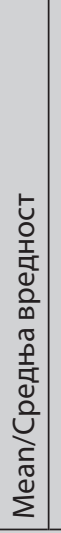 & 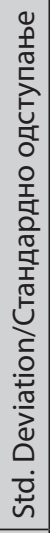 \\
\hline & & & & 날 & 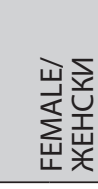 & & $\begin{array}{l}\underset{⿱}{\sim} \\
\vdots \\
\infty \\
\infty\end{array}$ & & 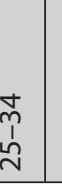 & $\begin{array}{l}\text { y } \\
\text { in } \\
m\end{array}$ & & $\begin{array}{l}4 \\
1 \\
1 \\
y\end{array}$ & 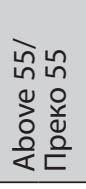 & 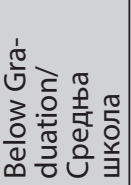 & \multicolumn{2}{|c|}{ 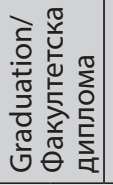 } & 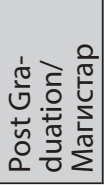 & \multicolumn{2}{|c|}{ 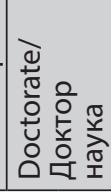 } \\
\hline & & & \multicolumn{3}{|c|}{$\begin{array}{l}\frac{5}{0} \\
\frac{5}{d} \\
\frac{0}{0} \\
\frac{\delta}{d} \\
0\end{array}$} & \multicolumn{8}{|c|}{ 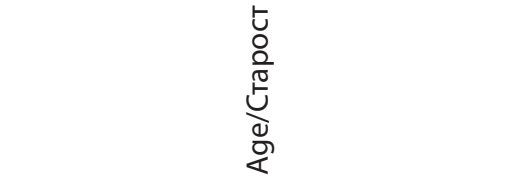 } & \multicolumn{6}{|c|}{ 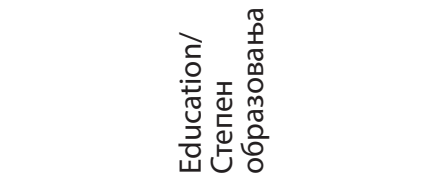 } \\
\hline
\end{tabular}


Table 3: Factors affecting Hygiene behaviour $(\mathrm{N}=700)$ /

\begin{tabular}{|c|c|c|c|c|c|}
\hline \multicolumn{4}{|c|}{ Personal Demographic Variable } & $\begin{array}{l}\text { Hand washing } \\
\text { after sneezing, } \\
\text { coughing or } \\
\text { touching nose }\end{array}$ & $\begin{array}{c}\text { Use of Soap } \\
\text { when washing } \\
\text { hands }\end{array}$ \\
\hline \multirow{4}{*}{ Gender } & \multirow[t]{3}{*}{ MALE } & \multicolumn{2}{|l|}{ B } & 1,03 & 1,02 \\
\hline & & \multirow{2}{*}{$\begin{array}{l}95 \% \\
\text { Confidence } \\
\text { Interval for } \operatorname{Exp}(\mathrm{B})\end{array}$} & Lower Bound & 0,51 & 0,53 \\
\hline & & & Upper Bound & 1,06 & 1,07 \\
\hline & \multicolumn{3}{|c|}{ Female } & $\begin{array}{c}1,00 \\
\text { (reference) }\end{array}$ & $\begin{array}{c}1,00 \\
\text { (reference) }\end{array}$ \\
\hline \multirow{13}{*}{ Age Group } & \multirow[t]{3}{*}{$18-24$} & \multicolumn{2}{|l|}{ B } & 1,52 & 0,8 \\
\hline & & \multirow{2}{*}{$\begin{array}{l}95 \% \\
\text { Confidence } \\
\text { Interval for } \operatorname{Exp}(B)\end{array}$} & Lower Bound & 0,3 & 0,22 \\
\hline & & & Upper Bound & 1,17 & 0,92 \\
\hline & \multirow[t]{3}{*}{$25-34$} & \multicolumn{2}{|l|}{ B } & 1,07 & 0,48 \\
\hline & & \multirow{2}{*}{$\begin{array}{l}95 \% \\
\text { Confidence } \\
\text { Interval for } \operatorname{Exp}(\mathrm{B})\end{array}$} & Lower Bound & 0,53 & 0,33 \\
\hline & & & Upper Bound & 1,66 & 1,15 \\
\hline & \multirow[t]{3}{*}{$35-44$} & \multicolumn{2}{|l|}{ B } & 1,09 & 0,69 \\
\hline & & \multirow{2}{*}{$\begin{array}{l}95 \% \\
\text { Confidence } \\
\text { Interval for Exp(B) }\end{array}$} & LowerBound & 0,5 & 0,26 \\
\hline & & & Upper Bound & 1,68 & 0,98 \\
\hline & $45-54$ & \multicolumn{2}{|l|}{ B } & 0,28 & 0,74 \\
\hline & & \multirow{2}{*}{$\begin{array}{l}95 \% \\
\text { Confidence } \\
\text { Interval for Exp(B) }\end{array}$} & Upper Bound & 0,64 & 0,19 \\
\hline & & & Upper Bound & 2,73 & 1,17 \\
\hline & \multicolumn{3}{|c|}{ Above 55} & $\begin{array}{c}1,00 \\
\text { (reference) }\end{array}$ & $\begin{array}{c}1,00 \\
\text { (reference) }\end{array}$ \\
\hline \multirow{10}{*}{ Education } & \multirow{3}{*}{$\begin{array}{l}\text { Gradua- } \\
\text { tion }\end{array}$} & \multirow{3}{*}{\begin{tabular}{|l} 
B \\
$95 \%$ \\
Confidence \\
Interval for Exp(B) \\
\end{tabular}} & & 3,15 & 3,47 \\
\hline & & & Lower Bound & 0,13 & 1,23 \\
\hline & & & Upper Bound & 1,12 & 2,56 \\
\hline & \multirow{3}{*}{$\begin{array}{l}\text { Post Gra- } \\
\text { duation }\end{array}$} & \multicolumn{2}{|l|}{$\mathrm{B}$} & 3,10 & 2,91 \\
\hline & & \multirow{2}{*}{$\begin{array}{l}95 \% \\
\text { Confidence } \\
\text { Interval for } \operatorname{Exp}(\mathrm{B}\end{array}$} & Lower Bound & 0,51 & 0,21 \\
\hline & & & Lower Bound & 2,68 & 1,98 \\
\hline & \multirow{3}{*}{ Doctorate } & \multicolumn{2}{|l|}{ B } & 3,43 & 3,14 \\
\hline & & \multirow{2}{*}{$\begin{array}{l}95 \% \\
\text { Confidence } \\
\text { Interval for Exp(B) }\end{array}$} & Lower Bound & 0,31 & 0,33 \\
\hline & & & Upper Bound & 1,23 & 1,37 \\
\hline & \multicolumn{3}{|c|}{ Below Graduation } & $\begin{array}{c}1,00 \\
\text { (reference) }\end{array}$ & $\begin{array}{c}1,00 \\
\text { (reference) }\end{array}$ \\
\hline
\end{tabular}

\begin{tabular}{|c|c|c|c|c|c|c|}
\hline $\begin{array}{l}\text { Hand washing } \\
\text { after returning } \\
\text { home }\end{array}$ & $\begin{array}{l}\text { Hand washing } \\
\text { after touching } \\
\text { outside } \\
\text { objects }\end{array}$ & $\begin{array}{l}\text { Hand } \\
\text { washing } \\
\text { after } \\
\text { touching } \\
\text { cash }\end{array}$ & \begin{tabular}{|c|} 
Hand \\
washing after \\
touching \\
Handrails, \\
handles, or \\
doorknobs
\end{tabular} & $\begin{array}{c}\text { Hand } \\
\text { washing } \\
\text { after } \\
\text { touching } \\
\text { used kitchen } \\
\text { sponges or } \\
\text { towels }\end{array}$ & $\begin{array}{l}\text { Wash your } \\
\text { hands before } \\
\text { preparing a } \\
\text { meal and after } \\
\text { handling raw } \\
\text { food items }\end{array}$ & $\begin{array}{l}\text { Frequency of } \\
\text { cleaning or } \\
\text { disinfecting } \\
\text { house }\end{array}$ \\
\hline 0,23 & 0,78 & 1,18 & 0,28 & 1,19 & 1,04 & 1,01 \\
\hline 0,86 & 0,62 & 0,91 & 0,97 & 0,62 & 0,69 & 0,58 \\
\hline 1,87 & 1,39 & 1,57 & 1,79 & 1,11 & 1,34 & 0,85 \\
\hline $\begin{array}{c}1,00 \\
\text { (reference) }\end{array}$ & $\begin{array}{c}1,00 \\
\text { (reference) }\end{array}$ & $\begin{array}{c}1,00 \\
\text { (reference) }\end{array}$ & $\begin{array}{c}1,00 \\
\text { (reference) }\end{array}$ & $\begin{array}{c}1,00 \\
\text { (reference) }\end{array}$ & $\begin{array}{c}1,00 \\
\text { (reference) }\end{array}$ & $\begin{array}{c}1,00 \\
\text { (reference) }\end{array}$ \\
\hline 1,96 & 0,22 & 0,28 & 0,37 & 0,79 & 1,68 & $-0,96$ \\
\hline 0,2 & 0,61 & 0,46 & 0,82 & 1,24 & 0,28 & 0,27 \\
\hline 0,75 & 2,56 & 1,24 & 2,56 & 3,88 & 0,92 & 0,55 \\
\hline 0,77 & 0,6 & 0,69 & 0,1 & 0,83 & 0,76 & $-0,66$ \\
\hline 0,25 & 0,95 & 0,31 & 0,65 & 1,33 & 0,27 & 0,37 \\
\hline 0,84 & 3,5 & 0,82 & 1,9 & 3,96 & 0,8 & 0,71 \\
\hline 0,51 & 0,19 & 0,46 & 0,32 & 0,38 & $-0,1$ & $-0,79$ \\
\hline 0,32 & 0,41 & 0,38 & 0,78 & 0,83 & 0,52 & 0,32 \\
\hline 1,15 & 1,67 & 1,03 & 2,44 & 2,56 & 1,58 & 0,64 \\
\hline 0,06 & 0,22 & 0,77 & 0,35 & 1,15 & 0,86 & $-0,86$ \\
\hline 0,43 & 0,51 & 0,24 & 0,34 & 1,58 & 0,2 & 0,27 \\
\hline 2,65 & 3,07 & 0,88 & 1,45 & 6,34 & 0,91 & 0,67 \\
\hline $\begin{array}{c}1,00 \\
\text { (reference) }\end{array}$ & $\begin{array}{c}1,00 \\
\text { (reference) }\end{array}$ & $\begin{array}{c}1,00 \\
\text { (reference) }\end{array}$ & $\begin{array}{c}1,00 \\
\text { (reference) }\end{array}$ & $\begin{array}{c}1,00 \\
\text { (reference) }\end{array}$ & $\begin{array}{c}1,00 \\
\text { (reference) }\end{array}$ & $\begin{array}{c}1,00 \\
\text { (reference) }\end{array}$ \\
\hline 3,43 & 2,17 & 2,58 & 3,10 & 2,29 & 3,94 & $-3,39$ \\
\hline 0,2 & 0,41 & 1,46 & 1,82 & 1,2 & 0,32 & 0,27 \\
\hline 0,65 & 2,43 & 2,71 & 2,51 & 3,58 & 3,94 & 1,55 \\
\hline$-5,37$ & 3,11 & 2,44 & 3,12 & 2,60 & 3,65 & $-3,75$ \\
\hline 0,32 & 0,44 & 0,28 & 0,71 & 0,82 & 0,58 & 1,32 \\
\hline 1,12 & 1,54 & 1,04 & 2,49 & 2,51 & 2,58 & 0,62 \\
\hline$-5,31$ & 3,23 & 1,77 & 3,36 & 2,56 & 3,42 & 3,23 \\
\hline 0,85 & 0,64 & 0,92 & 0,91 & 0,66 & 0,71 & 0,61 \\
\hline 1,81 & 1,43 & 1,58 & 1,87 & 1,19 & 1,36 & 1,89 \\
\hline $\begin{array}{c}1,00 \\
\text { (reference) }\end{array}$ & $\begin{array}{c}1,00 \\
\text { (reference) }\end{array}$ & $\begin{array}{c}1,00 \\
\text { (reference) }\end{array}$ & $\begin{array}{c}1,00 \\
\text { (reference) }\end{array}$ & $\begin{array}{c}1,00 \\
\text { (reference) }\end{array}$ & $\begin{array}{c}1,00 \\
\text { (reference) }\end{array}$ & $\begin{array}{c}1,00 \\
\text { (reference) }\end{array}$ \\
\hline
\end{tabular}




\begin{tabular}{|c|c|c|c|c|c|}
\hline \multirow{10}{*}{$\begin{array}{l}\text { Self Health } \\
\text { Status }\end{array}$} & \multirow[t]{3}{*}{ Poor } & \multicolumn{2}{|l|}{ B } & $-0,45$ & 2,33 \\
\hline & & \multirow{2}{*}{$\begin{array}{l}95 \% \\
\text { Confidence } \\
\text { Interval for Exp(B) }\end{array}$} & Lower Bound & 0,15 & 2,16 \\
\hline & & & Upper Bound & 2,77 & 48,83 \\
\hline & \multirow[t]{3}{*}{ Fair } & \multicolumn{2}{|l|}{ B } & 0,16 & 0,76 \\
\hline & & \multirow{2}{*}{$\begin{array}{l}95 \% \\
\text { Confidence } \\
\text { Interval for Exp(B) }\end{array}$} & Lower Bound & 0,53 & 0,64 \\
\hline & & & Upper Bound & 2,58 & 7,10 \\
\hline & \multirow[t]{3}{*}{ Good } & \multicolumn{2}{|l|}{ B } & $-0,12$ & 1,10 \\
\hline & & \multirow{2}{*}{$\begin{array}{l}95 \% \\
\text { Confidence } \\
\text { Interval for Exp(B) }\end{array}$} & Lower Bound & 0,50 & 1,14 \\
\hline & & & Upper Bound & 1,58 & 7,89 \\
\hline & \multicolumn{3}{|c|}{ Excellent } & $\begin{array}{c}1,00 \\
\text { (reference) }\end{array}$ & $\begin{array}{c}1,00 \\
\text { (reference) }\end{array}$ \\
\hline \multirow{10}{*}{$\begin{array}{l}\text { Worried } \\
\text { if have } \\
\text { COVID-19 }\end{array}$} & \multirow{3}{*}{$\begin{array}{l}\text { Not at all } \\
\text { worried }\end{array}$} & \multicolumn{2}{|l|}{ B } & $-0,15$ & 0,11 \\
\hline & & \multirow{2}{*}{$\begin{array}{l}95 \% \\
\text { Confidence } \\
\text { Interval for } \operatorname{Exp}(\mathrm{B})\end{array}$} & Lower Bound & 0,45 & 0,52 \\
\hline & & & Upper Bound & 1,67 & 2,39 \\
\hline & \multirow{3}{*}{\begin{tabular}{|l} 
Much less \\
worried \\
than \\
normal
\end{tabular}} & \multicolumn{2}{|l|}{ B } & 0,11 & 0,20 \\
\hline & & \multirow{2}{*}{\begin{tabular}{|l|}
$95 \%$ \\
Confidence \\
Interval for $\operatorname{Exp}(B)$ \\
\end{tabular}} & Lower Bound & 0,64 & 0,42 \\
\hline & & & Upper Bound & 1,94 & 1,61 \\
\hline & \multirow{3}{*}{$\begin{array}{l}\text { Worried } \\
\text { more than } \\
\text { normal }\end{array}$} & \multicolumn{2}{|l|}{ B } & 0,01 & 0,39 \\
\hline & & \multirow{2}{*}{\begin{tabular}{|l|}
$95 \%$ \\
Confidence \\
Interval for Exp(B)
\end{tabular}} & Lower Bound & 0,59 & 0,79 \\
\hline & & & Upper Bound & 1,73 & 2,79 \\
\hline & \multicolumn{3}{|c|}{ Extremely worried } & $\begin{array}{c}1,00 \\
\text { (reference) }\end{array}$ & $\begin{array}{c}1,00 \\
\text { (reference) }\end{array}$ \\
\hline \multirow{10}{*}{ stress level } & \multirow[t]{3}{*}{ High } & \multicolumn{2}{|l|}{$B$} & 0,05 & 0,44 \\
\hline & & \multirow{2}{*}{\begin{tabular}{|l|}
$95 \%$ \\
Confidence \\
Interval for $\operatorname{Exp}(B)$
\end{tabular} \mid} & Lower Bound & 0,56 & 0,76 \\
\hline & & & Upper Bound & 1,97 & 3,19 \\
\hline & \multirow[t]{3}{*}{ Medium } & \multicolumn{2}{|c|}{ B } & 0,02 & $-0,44$ \\
\hline & & \multirow{2}{*}{\begin{tabular}{|l|}
$95 \%$ \\
Confidence \\
Interval for Exp(B) \\
\end{tabular}} & Lower Bound & 0,65 & 0,37 \\
\hline & & & Upper Bound & 1,62 & 1,12 \\
\hline & \multirow[t]{3}{*}{ Low } & \multicolumn{2}{|c|}{$\mathrm{B}$} & $-0,13$ & 0,08 \\
\hline & & $95 \%$ & Lower Bound & 0,53 & 0,61 \\
\hline & & Interval for $\operatorname{Exp}(\mathrm{B})$ & Upper Bound & 1,43 & 1,93 \\
\hline & & No Stres & & $\begin{array}{c}1,00 \\
\text { (reference) }\end{array}$ & $\begin{array}{c}1,00 \\
\text { (reference) }\end{array}$ \\
\hline
\end{tabular}

\begin{tabular}{|c|c|c|c|c|c|c|}
\hline 2,25 & 0,87 & $-0,81$ & $-0,71$ & $-0,63$ & $-0,75$ & 1,68 \\
\hline 1,66 & 0,42 & 0,13 & 0,14 & 0,17 & 0,12 & 2,68 \\
\hline 54,01 & 13,32 & 1,57 & 1,77 & 1,70 & 1,91 & 10,76 \\
\hline 1,86 & 0,38 & 0,68 & $-0,47$ & $-0,49$ & $-0,48$ & 0,65 \\
\hline 1,63 & 0,52 & 1,07 & 0,31 & 0,31 & 0,27 & 1,12 \\
\hline 25,50 & 4,07 & 3,63 & 1,26 & 1,20 & 1,43 & 3,30 \\
\hline 1,41 & 0,69 & 0,01 & $-0,68$ & $-0,06$ & $-0,33$ & 0,76 \\
\hline 1,15 & 0,88 & 0,62 & 0,31 & 0,59 & 0,39 & 1,40 \\
\hline 14,53 & 4,52 & 1,64 & 0,83 & 1,52 & 1,33 & 3,26 \\
\hline $\begin{array}{c}1,00 \\
\text { (reference) }\end{array}$ & $\begin{array}{c}1,00 \\
\text { (reference) }\end{array}$ & $\begin{array}{c}1,00 \\
\text { (reference) }\end{array}$ & $\begin{array}{c}1,00 \\
\text { (reference) }\end{array}$ & $\begin{array}{c}1,00 \\
\text { (reference) }\end{array}$ & $\begin{array}{c}1,00 \\
\text { (reference) }\end{array}$ & $\begin{array}{c}1,00 \\
\text { (reference) }\end{array}$ \\
\hline$-0,32$ & 0,16 & 0,08 & 0,27 & 0,16 & 0,00 & $-0,40$ \\
\hline 0,36 & 0,56 & 0,65 & 0,43 & 0,69 & 0,55 & 0,48 \\
\hline 1,45 & 2,47 & 1,80 & 1,34 & 1,99 & 1,85 & 0,93 \\
\hline 0,50 & 0,25 & 0,17 & $-0,19$ & 0,05 & 0,19 & $-0,45$ \\
\hline 0,34 & 0,68 & 0,76 & 0,51 & 0,66 & 0,73 & 0,48 \\
\hline 1,09 & 2,43 & 1,84 & 1,34 & 1,67 & 2,02 & 0,85 \\
\hline 0,82 & 0,36 & 0,29 & $-0,21$ & $-0,12$ & 0,15 & $-0,33$ \\
\hline 0,25 & 0,77 & 0,87 & 0,51 & 0,57 & 0,70 & 0,55 \\
\hline 0,77 & 2,66 & 2,06 & 1,30 & 1,39 & 1,91 & 0,94 \\
\hline $\begin{array}{c}1,00 \\
\text { (reference) }\end{array}$ & $\begin{array}{c}1,00 \\
\text { (reference) }\end{array}$ & $\begin{array}{c}1,00 \\
\text { (reference) }\end{array}$ & $\begin{array}{c}1,00 \\
\text { (reference) }\end{array}$ & $\begin{array}{c}1,00 \\
\text { (reference) }\end{array}$ & $\begin{array}{c}1,00 \\
\text { (reference) }\end{array}$ & $\begin{array}{c}1,00 \\
\text { (reference) }\end{array}$ \\
\hline 0,43 & 0,33 & 0,26 & $-0,10$ & $-0,18$ & $-0,07$ & $-0,37$ \\
\hline 0,31 & 0,66 & 0,75 & 0,51 & 0,48 & 0,50 & 0,48 \\
\hline 1,36 & 2,93 & 2,24 & 1,62 & 1,45 & 1,76 & 1,00 \\
\hline 0,02 & $-0,59$ & 0,57 & 0,11 & $-0,09$ & 0,38 & $-0,21$ \\
\hline 0,61 & 0,32 & 1,21 & 0,74 & 0,62 & 0,94 & 0,64 \\
\hline 1,70 & 0,96 & 2,60 & 1,67 & 1,35 & 2,30 & 1,04 \\
\hline$-0,38$ & 0,16 & 0,05 & $-0,01$ & 0,16 & 0,03 & 0,04 \\
\hline 0,39 & 0,66 & 0,69 & 0,64 & 0,78 & 0,64 & 0,81 \\
\hline 1,20 & 2,08 & 1,59 & 1,52 & 1,77 & 1,65 & 1,34 \\
\hline $\begin{array}{c}1,00 \\
\text { (reference) }\end{array}$ & $\begin{array}{c}1,00 \\
\text { (reference) }\end{array}$ & $\begin{array}{c}1,00 \\
\text { (reference) }\end{array}$ & $\begin{array}{c}1,00 \\
\text { (reference) }\end{array}$ & $\begin{array}{c}1,00 \\
\text { (reference) }\end{array}$ & $\begin{array}{c}1,00 \\
\text { (reference) }\end{array}$ & $\begin{array}{c}1,00 \\
\text { (reference) }\end{array}$ \\
\hline
\end{tabular}




\begin{tabular}{|c|c|c|c|c|c|}
\hline \multirow{7}{*}{$\begin{array}{l}\text { Mode of } \\
\text { transmis- } \\
\text { sion }\end{array}$} & \multirow[t]{3}{*}{ Droplets } & \multicolumn{2}{|l|}{ B } & 0,50 & 0,38 \\
\hline & & \multirow{2}{*}{$\begin{array}{l}95 \% \\
\text { Confidence } \\
\text { Interval for Exp(B) }\end{array}$} & Lower Bound & 0,75 & 0,59 \\
\hline & & & Upper Bound & 3,60 & 3,58 \\
\hline & \multirow{3}{*}{$\begin{array}{l}\text { Direct } \\
\text { Contact }\end{array}$} & \multicolumn{2}{|l|}{ B } & 0,35 & 0,47 \\
\hline & & \multirow{2}{*}{$\begin{array}{l}95 \% \\
\text { Confidence } \\
\text { Interval for Exp(B) }\end{array}$} & Lower Bound & 0,65 & 0,66 \\
\hline & & & Upper Bound & 3,07 & 3,84 \\
\hline & \multicolumn{3}{|c|}{ Indirect Contact } & $\begin{array}{c}1,00 \\
\text { (reference) }\end{array}$ & $\begin{array}{c}1,00 \\
\text { (reference) }\end{array}$ \\
\hline
\end{tabular}

Note: Responses to questions regarding behaviour were "always and / usually vs often and / never". Data are adjusted odds ratio ( $95 \%$ confidence level interval) unless otherwise noted,

estimates in bold are significant at $p<0.05$.

Табела 3: Фактори који утичу на понашање у смислу хигијене ( $\mathrm{N}=700)$

\begin{tabular}{|c|c|c|c|c|c|}
\hline \multicolumn{4}{|c|}{ Лична демографска варијабла } & $\begin{array}{l}\text { Прање руку } \\
\text { након кијања, } \\
\text { кашљања или }\end{array}$ & $\begin{array}{c}\text { Коришћење } \\
\text { сапуна } \\
\text { приликом }\end{array}$ \\
\hline \multirow{4}{*}{ Пол } & \multirow[t]{3}{*}{ МУШКИ } & \multicolumn{2}{|l|}{$B$} & 1,03 & 1,02 \\
\hline & & \multirow{2}{*}{$\begin{array}{l}95 \% \\
\text { Интервал пове- } \\
\text { рења за Ехр (В) }\end{array}$} & Инклинира нижем & 0,51 & 0,53 \\
\hline & & & Инклинира вишем & 1,06 & 1,07 \\
\hline & \multicolumn{3}{|c|}{ Женски } & $\begin{array}{c}1,00 \\
\text { (референтна) }\end{array}$ & $\begin{array}{c}1,00 \\
\text { (референтна) }\end{array}$ \\
\hline \multirow{13}{*}{$\begin{array}{c}\text { Старосна } \\
\text { група }\end{array}$} & \multirow[t]{3}{*}{$18-24$} & \multicolumn{2}{|l|}{ B } & 1,52 & 0,8 \\
\hline & & \multirow{2}{*}{$\begin{array}{l}\text { 95\% } \\
\text { Интервал пове- } \\
\text { рења за Ехр (В) }\end{array}$} & Инклинира нижем & 0,3 & 0,22 \\
\hline & & & Инклинира вишем & 1,17 & 0,92 \\
\hline & \multirow[t]{3}{*}{$25-34$} & \multicolumn{2}{|l|}{$B$} & 1,07 & 0,48 \\
\hline & & \multirow{2}{*}{$\begin{array}{l}95 \% \\
\text { Интервал пове- } \\
\text { рења за Ехр (В) }\end{array}$} & Инклинира нижем & 0,53 & 0,33 \\
\hline & & & Инклинира вишем & 1,66 & 1,15 \\
\hline & \multirow[t]{3}{*}{$35-44$} & \multicolumn{2}{|l|}{ B } & 1,09 & 0,69 \\
\hline & & \multirow{2}{*}{$\begin{array}{l}\text { 95\% } \\
\text { Интервал пове- } \\
\text { рења за Ехр (В) }\end{array}$} & Инклинира нижем & 0,5 & 0,26 \\
\hline & & & Инклинира вишем & 1,68 & 0,98 \\
\hline & $45-54$ & \multicolumn{2}{|l|}{$B$} & 0,28 & 0,74 \\
\hline & & \multirow{2}{*}{$\begin{array}{l}\text { 95\% } \\
\text { Интервал пове- } \\
\text { рења за Ехр (В) }\end{array}$} & Инклинира нижем & 0,64 & 0,19 \\
\hline & & & Инклинира вишем & 2,73 & 1,17 \\
\hline & \multicolumn{2}{|r|}{ Преко 55} & $\operatorname{Exp}(B)$ & $\begin{array}{c}1,00 \\
\text { (референтна) }\end{array}$ & $\begin{array}{c}1,00 \\
\text { (референтна) }\end{array}$ \\
\hline
\end{tabular}

\begin{tabular}{|c|c|c|c|c|c|c|}
\hline $\mathbf{0 , 2 0}$ & $-0,34$ & $-0,17$ & 0,25 & $-0,13$ & $\mathbf{0 , 2 7}$ & $\mathbf{0 , 5 4}$ \\
\hline 0,57 & 0,35 & 0,50 & 0,73 & 0,49 & 0,72 & 0,42 \\
\hline 2,61 & 1,46 & 1,42 & 2,25 & 1,56 & 2,39 & 0,81 \\
\hline$-0,23$ & $-0,68$ & $-0,49$ & $\mathbf{0 , 5 3}$ & 0,28 & $\mathbf{0 , 2 3}$ & $\mathbf{0 , 7 9}$ \\
\hline 0,38 & 0,25 & 0,37 & 0,99 & 0,75 & 0,70 & 0,33 \\
\hline 1,68 & 1,02 & 1,03 & 2,92 & 2,30 & 2,25 & 0,63 \\
\hline $\begin{array}{c}1,00 \\
\text { (reference) }\end{array}$ & $\begin{array}{c}1,00 \\
\text { (reference) }\end{array}$ & $\begin{array}{c}1,00 \\
\text { (reference) }\end{array}$ & $\begin{array}{c}1,00 \\
\text { (reference) }\end{array}$ & $\begin{array}{c}1,00 \\
\text { (reference) }\end{array}$ & $\begin{array}{c}1,00 \\
\text { (reference) }\end{array}$ & $\begin{array}{c}1,00 \\
\text { (reference) }\end{array}$ \\
\hline
\end{tabular}

\begin{tabular}{|c|c|c|c|c|c|c|}
\hline $\begin{array}{c}\text { Прање } \\
\text { руку након } \\
\text { доласка кући }\end{array}$ & $\begin{array}{c}\text { Прање } \\
\text { руку након } \\
\text { додиривања } \\
\text { предмета } \\
\text { ван куће }\end{array}$ & $\begin{array}{c}\text { Прање } \\
\text { руку након } \\
\text { додири- } \\
\text { вања новца }\end{array}$ & $\begin{array}{c}\text { Прање } \\
\text { руку након } \\
\text { додиривања } \\
\text { гелендера, } \\
\text { ручки или } \\
\text { квака }\end{array}$ & $\begin{array}{c}\text { Прање } \\
\text { руку након } \\
\text { додиривања } \\
\text { коришћених } \\
\text { кухињских } \\
\text { сунђера или } \\
\text { крпа } \\
\end{array}$ & $\begin{array}{c}\text { Прање руку } \\
\text { пре припреме } \\
\text { оброка } \\
\text { или након } \\
\text { додиривања } \\
\text { сирових } \\
\text { намирница. }\end{array}$ & $\begin{array}{c}\text { Учесталост } \\
\text { чишћења или } \\
\text { дезинфекције } \\
\text { стамбеног } \\
\text { простора }\end{array}$ \\
\hline 0,23 & 0,78 & 1,18 & 0,28 & 1,19 & 1,04 & 1,01 \\
\hline 0,86 & 0,62 & 0,91 & 0,97 & 0,62 & 0,69 & 0,58 \\
\hline 1,87 & 1,39 & 1,57 & 1,79 & 1,11 & 1,34 & 0,85 \\
\hline $\begin{array}{c}1,00 \\
\text { (референтна) }\end{array}$ & $\begin{array}{c}1,00 \\
\text { (референтна) }\end{array}$ & $\begin{array}{c}1,00 \\
\text { (референтна) }\end{array}$ & $\begin{array}{c}1,00 \\
\text { (референтна) }\end{array}$ & $\begin{array}{c}1,00 \\
\text { (референтна) }\end{array}$ & $\begin{array}{c}1,00 \\
\text { (референтна) }\end{array}$ & $\begin{array}{c}1,00 \\
\text { (референтна) }\end{array}$ \\
\hline 1,96 & 0,22 & 0,28 & 0,37 & 0,79 & 1,68 & $-0,96$ \\
\hline 0,2 & 0,61 & 0,46 & 0,82 & 1,24 & 0,28 & 0,27 \\
\hline 0,75 & 2,56 & 1,24 & 2,56 & 3,88 & 0,92 & 0,55 \\
\hline 0,77 & 0,6 & 0,69 & 0,1 & 0,83 & 0,76 & $-0,66$ \\
\hline 0,25 & 0,95 & 0,31 & 0,65 & 1,33 & 0,27 & 0,37 \\
\hline 0,84 & 3,5 & 0,82 & 1,9 & 3,96 & 0,8 & 0,71 \\
\hline 0,51 & 0,19 & 0,46 & 0,32 & 0,38 & $-0,1$ & $-0,79$ \\
\hline 0,32 & 0,41 & 0,38 & 0,78 & 0,83 & 0,52 & 0,32 \\
\hline 1,15 & 1,67 & 1,03 & 2,44 & 2,56 & 1,58 & 0,64 \\
\hline 0,06 & 0,22 & 0,77 & 0,35 & 1,15 & 0,86 & $-0,86$ \\
\hline 0,43 & 0,51 & 0,24 & 0,34 & 1,58 & 0,2 & 0,27 \\
\hline 2,65 & 3,07 & 0,88 & 1,45 & 6,34 & 0,91 & 0,67 \\
\hline $\begin{array}{c}1,00 \\
\text { (референтна) }\end{array}$ & $\begin{array}{c}1,00 \\
\text { (референтна) }\end{array}$ & $\begin{array}{c}1,00 \\
\text { (референтна) }\end{array}$ & $\begin{array}{c}1,00 \\
\text { (референтна) }\end{array}$ & $\begin{array}{c}1,00 \\
\text { (референтна) }\end{array}$ & $\begin{array}{c}1,00 \\
\text { (референтна) }\end{array}$ & $\begin{array}{c}1,00 \\
\text { (референтна) }\end{array}$ \\
\hline
\end{tabular}




\begin{tabular}{|c|c|c|c|c|c|}
\hline \multirow{10}{*}{$\begin{array}{l}\text { Степен } \\
\text { образо- } \\
\text { вања }\end{array}$} & \multirow{3}{*}{\begin{tabular}{|l} 
Факул- \\
тетска \\
диплома
\end{tabular}} & \multicolumn{2}{|l|}{ B } & 3,15 & 3,47 \\
\hline & & \multirow{2}{*}{$\begin{array}{l}95 \% \\
\text { Интервал пове- } \\
\text { рења за Ехр (В) }\end{array}$} & Инклинира нижем & 0,13 & 1,23 \\
\hline & & & Инклинира вишем & 1,12 & 2,56 \\
\hline & \multirow{3}{*}{ Магистар } & \multicolumn{2}{|l|}{ B } & 3,10 & 2,91 \\
\hline & & \multirow{2}{*}{$\begin{array}{l}\text { 95\% } \\
\text { Интервал пове- } \\
\text { рења за Ехр (В) }\end{array}$} & Инклинира нижем & 0,51 & 0,21 \\
\hline & & & Инклинира вишем & 2,68 & 1,98 \\
\hline & \multirow{3}{*}{$\begin{array}{l}\text { Доктор } \\
\text { наука }\end{array}$} & \multicolumn{2}{|l|}{ B } & 3,43 & 3,14 \\
\hline & & \multirow{2}{*}{$\begin{array}{l}\text { 95\% } \\
\text { Интервал пове- } \\
\text { рења за Ехр (В) }\end{array}$} & Инклинира нижем & 0,31 & 0,33 \\
\hline & & & Инклинира вишем & 1,23 & 1,37 \\
\hline & \multicolumn{3}{|c|}{ Средња школа } & $\begin{array}{c}1,00 \\
\text { (референтна) }\end{array}$ & $\begin{array}{c}1,00 \\
\text { (референтна) }\end{array}$ \\
\hline \multirow{10}{*}{$\begin{array}{l}\text { Лична } \\
\text { процена } \\
\text { здравстве- } \\
\text { ног стања }\end{array}$} & \multirow[t]{3}{*}{ Лоше } & \multicolumn{2}{|l|}{ B } & $-0,45$ & 2,33 \\
\hline & & \multirow{2}{*}{\begin{tabular}{|l|}
$95 \%$ \\
Интервал пове- \\
рења за Ехр (В) \\
\end{tabular}} & Инклинира нижем & 0,15 & 2,16 \\
\hline & & & Инклинира вишем & 2,77 & 48,83 \\
\hline & \multirow{3}{*}{\begin{tabular}{|l|} 
При- \\
хватљиво
\end{tabular}} & \multicolumn{2}{|l|}{$\mathrm{B}$} & 0,16 & 0,76 \\
\hline & & \multirow{2}{*}{$\begin{array}{l}95 \% \\
\text { Интервал пове- } \\
\text { рења за Ехр (В) } \\
\end{array}$} & Инклинира нижем & 0,53 & 0,64 \\
\hline & & & Инклинира вишем & 2,58 & 7,10 \\
\hline & \multirow[t]{3}{*}{ Добро } & \multicolumn{2}{|l|}{$\mathrm{B}$} & $-0,12$ & 1,10 \\
\hline & & \multirow{2}{*}{\begin{tabular}{|l|}
$95 \%$ \\
Интервал пове- \\
рења за Ехр (В) \\
\end{tabular}} & Инклинира нижем & 0,50 & 1,14 \\
\hline & & & Инклинира вишем & 1,58 & 7,89 \\
\hline & \multicolumn{3}{|c|}{ Одлично } & $\begin{array}{c}1,00 \\
\text { (референтна) }\end{array}$ & $\begin{array}{c}1,00 \\
\text { (референтна) }\end{array}$ \\
\hline \multirow{10}{*}{$\begin{array}{l}\text { Забри- } \\
\text { нут/а да } \\
\text { ли има } \\
\text { COVID-19 }\end{array}$} & \multirow{3}{*}{\begin{tabular}{|l} 
Уопште \\
није \\
забри- \\
нут/а
\end{tabular}} & \multicolumn{2}{|l|}{ B } & $-0,15$ & 0,11 \\
\hline & & \multirow{2}{*}{\begin{tabular}{|l|}
$95 \%$ \\
Интервал пове- \\
рења за Ехр (В) \\
\end{tabular}} & Инклинира нижем & 0,45 & 0,52 \\
\hline & & & Инклинира вишем & 1,67 & 2,39 \\
\hline & /Много & \multicolumn{2}{|l|}{ B } & 0,11 & 0,20 \\
\hline & $\begin{array}{l}\text { мање } \\
\text { забри- }\end{array}$ & \multirow{2}{*}{$\begin{array}{l}\text { 95\% } \\
\text { Интервал пове- } \\
\text { рења за Ехр (В) }\end{array}$} & Инклинира нижем & 0,64 & 0,42 \\
\hline & $\begin{array}{l}\text { што је } \\
\text { нормално }\end{array}$ & & Инклинира вишем & 1,94 & 1,61 \\
\hline & \multirow{3}{*}{\begin{tabular}{|l|} 
Забри- \\
нут/а \\
више него \\
што је \\
нормално
\end{tabular}} & \multicolumn{2}{|l|}{ B } & 0,01 & 0,39 \\
\hline & & \multirow{2}{*}{$\begin{array}{l}\text { 95\% } \\
\text { Интервал пове- } \\
\text { рења за Ехр (В) }\end{array}$} & Инклинира нижем & 0,59 & 0,79 \\
\hline & & & Инклинира вишем & 1,73 & 2,79 \\
\hline & Изузетно з & забринут/а & & $\begin{array}{c}1,00 \\
\text { (референтна) }\end{array}$ & $\begin{array}{c}1,00 \\
\text { (референтна) }\end{array}$ \\
\hline
\end{tabular}

\begin{tabular}{|c|c|c|c|c|c|c|}
\hline 3,43 & 2,17 & 2,58 & 3,10 & 2,29 & 3,94 & $-3,39$ \\
\hline 0,2 & 0,41 & 1,46 & 1,82 & 1,2 & 0,32 & 0,27 \\
\hline 0,65 & 2,43 & 2,71 & 2,51 & 3,58 & 3,94 & 1,55 \\
\hline$-5,37$ & 3,11 & 2,44 & 3,12 & 2,60 & 3,65 & $-3,75$ \\
\hline 0,32 & 0,44 & 0,28 & 0,71 & 0,82 & 0,58 & 1,32 \\
\hline 1,12 & 1,54 & 1,04 & 2,49 & 2,51 & 2,58 & 0,62 \\
\hline$-5,31$ & 3,23 & 1,77 & 3,36 & 2,56 & 3,42 & 3,23 \\
\hline 0,85 & 0,64 & 0,92 & 0,91 & 0,66 & 0,71 & 0,61 \\
\hline 1,81 & 1,43 & 1,58 & 1,87 & 1,19 & 1,36 & 1,89 \\
\hline $\begin{array}{c}1,00 \\
\text { (референтна) }\end{array}$ & $\begin{array}{c}1,00 \\
\text { (референтна) }\end{array}$ & $\begin{array}{c}1,00 \\
\text { (референтна) }\end{array}$ & $\begin{array}{c}1,00 \\
\text { (референтна) }\end{array}$ & $\begin{array}{c}1,00 \\
\text { (референтна) }\end{array}$ & $\begin{array}{c}1,00 \\
\text { (референтна) }\end{array}$ & $\begin{array}{c}1,00 \\
\text { (референтна) }\end{array}$ \\
\hline 2,25 & 0,87 & \begin{tabular}{|l|}
$-0,81$ \\
\end{tabular} & $-0,71$ & $-0,63$ & $-0,75$ & 1,68 \\
\hline 1,66 & 0,42 & 0,13 & 0,14 & 0,17 & 0,12 & 2,68 \\
\hline 54,01 & 13,32 & 1,57 & 1,77 & 1,70 & 1,91 & 10,76 \\
\hline 1,86 & 0,38 & 0,68 & $-0,47$ & $-0,49$ & $-0,48$ & 0,65 \\
\hline 1,63 & 0,52 & 1,07 & 0,31 & 0,31 & 0,27 & 1,12 \\
\hline 25,50 & 4,07 & 3,63 & 1,26 & 1,20 & 1,43 & 3,30 \\
\hline 1,41 & 0,69 & 0,01 & $-0,68$ & $-0,06$ & $-0,33$ & 0,76 \\
\hline 1,15 & 0,88 & 0,62 & 0,31 & 0,59 & 0,39 & 1,40 \\
\hline 14,53 & 4,52 & 1,64 & 0,83 & 1,52 & 1,33 & 3,26 \\
\hline $\begin{array}{c}1,00 \\
\text { (референтна) }\end{array}$ & $\begin{array}{c}1,00 \\
\text { (референтна) }\end{array}$ & $\begin{array}{c}1,00 \\
\text { (референтна) }\end{array}$ & $\begin{array}{c}1,00 \\
\text { (референтна) }\end{array}$ & $\begin{array}{c}1,00 \\
\text { (референтна) }\end{array}$ & $\begin{array}{c}1,00 \\
\text { (референтна) }\end{array}$ & $\begin{array}{c}1,00 \\
\text { (референтна) }\end{array}$ \\
\hline$-0,32$ & $\begin{array}{l}0,16 \\
\end{array}$ & $\begin{array}{l}0,08 \\
\end{array}$ & $\begin{array}{l}0,27 \\
\end{array}$ & 0,16 & 0,00 & $-0,40$ \\
\hline 0,36 & 0,56 & 0,65 & 0,43 & 0,69 & 0,55 & 0,48 \\
\hline 1,45 & 2,47 & 1,80 & 1,34 & 1,99 & 1,85 & 0,93 \\
\hline 0,50 & 0,25 & 0,17 & $-0,19$ & 0,05 & 0,19 & $-0,45$ \\
\hline 0,34 & 0,68 & 0,76 & 0,51 & 0,66 & 0,73 & 0,48 \\
\hline 1,09 & 2,43 & 1,84 & 1,34 & 1,67 & 2,02 & 0,85 \\
\hline 0,82 & 0,36 & 0,29 & $-0,21$ & $-0,12$ & 0,15 & $-0,33$ \\
\hline 0,25 & 0,77 & 0,87 & 0,51 & 0,57 & 0,70 & 0,55 \\
\hline 0,77 & 2,66 & 2,06 & 1,30 & 1,39 & 1,91 & 0,94 \\
\hline $\begin{array}{c}1,00 \\
\text { (референтна) }\end{array}$ & $\begin{array}{c}1,00 \\
\text { (референтна) }\end{array}$ & $\begin{array}{c}1,00 \\
\text { (референтна) }\end{array}$ & $\begin{array}{c}1,00 \\
\text { (референтна) }\end{array}$ & $\begin{array}{c}1,00 \\
\text { (референтна) }\end{array}$ & $\begin{array}{c}1,00 \\
\text { (референтна) }\end{array}$ & $\begin{array}{c}1,00 \\
\text { (референтна) }\end{array}$ \\
\hline
\end{tabular}




\begin{tabular}{|c|c|c|c|c|c|}
\hline \multirow{10}{*}{$\begin{array}{l}\text { ниво } \\
\text { стреса }\end{array}$} & \multirow[t]{3}{*}{ Висок } & \multicolumn{2}{|l|}{ B } & 0,05 & 0,44 \\
\hline & & \multirow{2}{*}{$\begin{array}{l}\text { 95\% } \\
\text { Интервал пове- } \\
\text { рења за Ехр (В) }\end{array}$} & Инклинира нижем & 0,56 & 0,76 \\
\hline & & & Инклинира вишем & 1,97 & 3,19 \\
\hline & \multirow[t]{3}{*}{ Средњи } & \multicolumn{2}{|l|}{ B } & 0,02 & $-0,44$ \\
\hline & & \multirow{2}{*}{$\begin{array}{l}\text { 95\% } \\
\text { Интервал пове- } \\
\text { рења за Ехр (В) }\end{array}$} & Инклинира нижем & 0,65 & 0,37 \\
\hline & & & Инклинира вишем & 1,62 & 1,12 \\
\hline & \multirow[t]{3}{*}{ Низак } & \multicolumn{2}{|l|}{ B } & $-0,13$ & 0,08 \\
\hline & & \multirow{2}{*}{$\begin{array}{l}95 \% \\
\text { Интервал пове- } \\
\text { рења за Ехр (В) }\end{array}$} & Инклинира нижем & 0,53 & 0,61 \\
\hline & & & Инклинира вишем & 1,43 & 1,93 \\
\hline & \multicolumn{3}{|c|}{ Стрес није присутан } & $\begin{array}{c}1,00 \\
\text { (референтна) }\end{array}$ & $\begin{array}{c}1,00 \\
\text { (референтна) }\end{array}$ \\
\hline \multirow{7}{*}{$\begin{array}{l}\text { Начин } \\
\text { трансми- } \\
\text { сије }\end{array}$} & \multirow{3}{*}{$\begin{array}{l}\text { Капљич- } \\
\text { но }\end{array}$} & \multicolumn{2}{|l|}{ B } & 0,50 & 0,38 \\
\hline & & \multirow{2}{*}{$\begin{array}{l}\text { 95\% } \\
\text { Интервал пове- } \\
\text { рења за Ехр (В) }\end{array}$} & Инклинира нижем & 0,75 & 0,59 \\
\hline & & & Инклинира вишем & 3,60 & 3,58 \\
\hline & \multirow{3}{*}{$\begin{array}{l}\text { Директан } \\
\text { контакт }\end{array}$} & \multicolumn{2}{|l|}{ B } & 0,35 & 0,47 \\
\hline & & \multirow{2}{*}{$\begin{array}{l}95 \% \\
\text { Интервал пове- } \\
\text { рења за Ехр (В) }\end{array}$} & Инклинира нижем & 0,65 & 0,66 \\
\hline & & & Инклинира вишем & 3,07 & 3,84 \\
\hline & \multicolumn{3}{|c|}{ Индиректан контакт } & $\begin{array}{c}1,00 \\
\text { (референтна) }\end{array}$ & $\begin{array}{c}1,00 \\
\text { (референтна) }\end{array}$ \\
\hline
\end{tabular}

Напомена: Одговори на питања у вези са понашањем били су "увек и / обично" наспрам "често и / никад". Подаци представљају прилагођени показатељ вероватноће (интервал нивоа поверења од 95\%); осим уколико није другачије назначено, процене написане подебљаним словима су значајне при $\mathrm{p}<0,05$.

\begin{tabular}{|c|c|c|c|c|c|c|}
\hline $\mathbf{0 , 4 3}$ & 0,33 & $\mathbf{0 , 2 6}$ & $-0,10$ & $-0,18$ & $-0,07$ & $\mathbf{- 0 , 3 7}$ \\
\hline 0,31 & 0,66 & 0,75 & 0,51 & 0,48 & 0,50 & 0,48 \\
\hline 1,36 & 2,93 & 2,24 & 1,62 & 1,45 & 1,76 & 1,00 \\
\hline 0,02 & $-\mathbf{0 , 5 9}$ & $\mathbf{0 , 5 7}$ & 0,11 & $-0,09$ & $\mathbf{0 , 3 8}$ & $-0,21$ \\
\hline 0,61 & 0,32 & 1,21 & 0,74 & 0,62 & 0,94 & 0,64 \\
\hline 1,70 & 0,96 & 2,60 & 1,67 & 1,35 & 2,30 & 1,04 \\
\hline$-0,38$ & 0,16 & 0,05 & $-0,01$ & 0,16 & 0,03 & 0,04 \\
\hline 0,39 & 0,66 & 0,69 & 0,64 & 0,78 & 0,64 & 0,81 \\
\hline 1,20 & 2,08 & 1,59 & 1,52 & 1,77 & 1,65 & 1,34 \\
\hline 1,00 & 1,00 & 1,00 & 1,00 & 1,00 & 1,00 & 1,00 \\
(референтна) & (референтна) & (референтна) & (референтна) & (референтна) & (референтна) & (референтна) \\
\hline $\mathbf{0 , 2 0}$ & $-0,34$ & $-0,17$ & 0,25 & $-0,13$ & $\mathbf{0 , 2 7}$ & $\mathbf{0 , 5 4}$ \\
\hline 0,57 & 0,35 & 0,50 & 0,73 & 0,49 & 0,72 & 0,42 \\
\hline 2,61 & 1,46 & 1,42 & 2,25 & 1,56 & 2,39 & 0,81 \\
\hline$-0,23$ & $-0,68$ & $-0,49$ & $\mathbf{0 , 5 3}$ & 0,28 & $\mathbf{0 , 2 3}$ & $\mathbf{0 , 7 9}$ \\
\hline 0,38 & 0,25 & 0,37 & 0,99 & 0,75 & 0,70 & 0,33 \\
\hline 1,68 & 1,02 & 1,03 & 2,92 & 2,30 & 2,25 & 0,63 \\
\hline 1,00 & 1,00 & 1,00 & 1,00 & 1,00 & 1,00 & 1,00 \\
(референтна) & (референтна) & (референтна) & (референтна) & (референтна) & (референтна) & (референтна) \\
\hline
\end{tabular}


Table 4 : Factors Affecting Better Cough Etiquette and Face Mask Use $(\mathrm{N}=700)$

Табела 4: Фактори који утичу на строго придржавање правила понашања приликом кашљања и употребу заштитне маске $(\mathrm{N}=700)$

\begin{tabular}{|c|c|c|c|c|c|}
\hline \multicolumn{4}{|c|}{ Personal Demographic Variable/Лична демографска варијабла } & $\begin{array}{l}\text { Covered } \\
\text { mouth while } \\
\text { sneezing or } \\
\text { coughing/ } \\
\text { Покрива уста } \\
\text { приликом } \\
\text { кијања или } \\
\text { кашљања }\end{array}$ & $\begin{array}{l}\text { Wear a Face } \\
\text { mask when } \\
\text { go outside/ } \\
\text { Носи } \\
\text { заштитну } \\
\text { маску за } \\
\text { лице на } \\
\text { отвореном }\end{array}$ \\
\hline \multirow{4}{*}{$\begin{array}{l}\text { Gender/ } \\
\text { Пол }\end{array}$} & \multirow{3}{*}{$\begin{array}{l}\text { MALE/ } \\
\text { MУШКИ }\end{array}$} & \multicolumn{2}{|l|}{ B } & $-0,335$ & 0,069 \\
\hline & & $\begin{array}{l}95 \% \\
\text { Confidence Interval }\end{array}$ & $\begin{array}{l}\text { Lower Bound/ } \\
\text { Инклинира нижем }\end{array}$ & 0,502 & 0,914 \\
\hline & & $\begin{array}{l}\text { for } \operatorname{Exp(B)/Интервал~} \\
\text { поверења за Ехр (B) }\end{array}$ & $\begin{array}{l}\text { Upper Bound/ } \\
\text { Инклинира вишем }\end{array}$ & 1,020 & 1,255 \\
\hline & \multicolumn{3}{|c|}{ Female/Женски } & $\begin{array}{c}1,00 \\
\text { (reference)/ } \\
\text { (референтна) }\end{array}$ & $\begin{array}{c}1,00 \\
\text { (reference)/ } \\
\text { (референтна) }\end{array}$ \\
\hline \multirow{14}{*}{$\begin{array}{l}\text { Age } \\
\text { Group/ } \\
\text { Cтаросна } \\
\text { група }\end{array}$} & \multirow{4}{*}{$18-24$} & \multicolumn{2}{|l|}{ B } & $-0,026$ & $-0,647$ \\
\hline & & \multicolumn{2}{|l|}{ Sig. } & 0,929 & 0,000 \\
\hline & & $\begin{array}{l}95 \% \\
\text { Confidence Interval }\end{array}$ & $\begin{array}{l}\text { Lower Bound/ } \\
\text { Инклинира нижем }\end{array}$ & 0,546 & 0,405 \\
\hline & & $\begin{array}{l}\text { for } \operatorname{Exp(B)/Интервал~} \\
\text { поверења за Ехр (B) }\end{array}$ & $\begin{array}{l}\text { Upper Bound/ } \\
\text { Инклинира вишем }\end{array}$ & 1,737 & 0,677 \\
\hline & \multirow{3}{*}{$25-34$} & B & & 0,090 & $-0,785$ \\
\hline & & \multirow{2}{*}{$\begin{array}{l}95 \% \\
\text { Confidence Interval } \\
\text { for Exp(B)/Интервал } \\
\text { поверења за Ехр (B) }\end{array}$} & $\begin{array}{l}\text { Lower Bound/ } \\
\text { Инклинира нижем }\end{array}$ & 0,546 & 0,363 \\
\hline & & & $\begin{array}{l}\text { Upper Bound/ } \\
\text { Инклинира вишем }\end{array}$ & 1,531 & 0,574 \\
\hline & \multirow{3}{*}{$35-44$} & \multicolumn{2}{|l|}{ B } & 0,253 & $-0,461$ \\
\hline & & $\begin{array}{l}95 \% \\
\text { Confidence Interval }\end{array}$ & $\begin{array}{l}\text { Lower Bound/ } \\
\text { Инклинира нижем }\end{array}$ & 0,449 & 0,500 \\
\hline & & $\begin{array}{l}\text { for } \operatorname{Exp(B)/Интервал~} \\
\text { поверења за Ехр (В) }\end{array}$ & $\begin{array}{l}\text { Upper Bound/ } \\
\text { Инклинира вишем }\end{array}$ & 1,343 & 0,795 \\
\hline & \multirow{3}{*}{$45-54$} & B & & 0,407 & $-0,524$ \\
\hline & & \multirow{2}{*}{$\begin{array}{l}95 \% \\
\text { Confidence Interval } \\
\text { for Exp(В)/Интервал } \\
\text { поверења за Ехр (В) }\end{array}$} & $\begin{array}{l}\text { Lower Bound/ } \\
\text { Инклинира нижем }\end{array}$ & 0,305 & 0,422 \\
\hline & & & $\begin{array}{l}\text { Upper Bound/ } \\
\text { Инклинира вишем }\end{array}$ & 1,451 & 0,831 \\
\hline & \multicolumn{3}{|c|}{ Above 55/Преко 55} & $\begin{array}{c}1,00 \\
\text { (reference)/ } \\
\text { (референтна) }\end{array}$ & $\begin{array}{c}1,00 \\
\text { (reference)/ } \\
\text { (peфepentra) }\end{array}$ \\
\hline
\end{tabular}

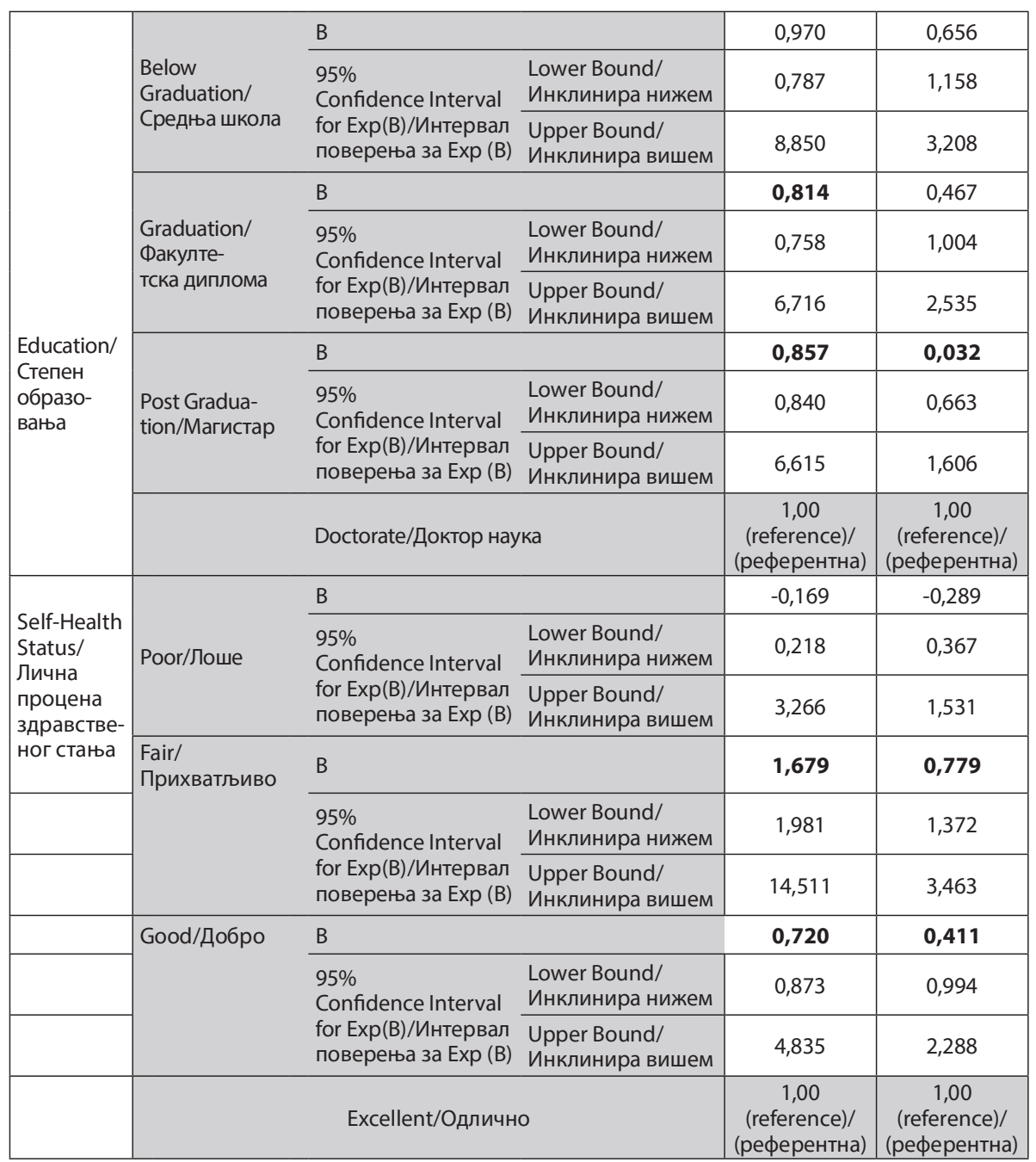




\begin{tabular}{|c|c|c|c|c|c|}
\hline \multirow{10}{*}{$\begin{array}{l}\text { Worried } \\
\text { if have } \\
\text { COVID-19/ } \\
\text { Забринут/а } \\
\text { да ли има } \\
\text { COVID-19 }\end{array}$} & \multirow{3}{*}{$\begin{array}{l}\text { Not at all } \\
\text { worried/ } \\
\text { Уопште није } \\
\text { забри- } \\
\text { нут/а }\end{array}$} & \multicolumn{2}{|l|}{ B } & \multirow{2}{*}{$\begin{array}{l}-0,045 \\
0,516\end{array}$} & \multirow{2}{*}{$\begin{array}{l}-0,179 \\
0,643\end{array}$} \\
\hline & & \multirow{2}{*}{$\begin{array}{l}95 \% \\
\text { Confidence Interval } \\
\text { for } \operatorname{Exp(B)/Интервал~} \\
\text { поверења за } \operatorname{Exp~(В)~}\end{array}$} & $\begin{array}{l}\text { Lower Bound/ } \\
\text { Инклинира нижем }\end{array}$ & & \\
\hline & & & $\begin{array}{l}\text { Upper Bound/ } \\
\text { Инклинира вишем }\end{array}$ & 1,773 & 1,087 \\
\hline & \multirow{3}{*}{\begin{tabular}{|l|} 
Much less \\
worried than \\
normal/ \\
Mного \\
мање \\
забринут/а \\
него што је \\
нормално \\
\end{tabular}} & B & & $-0,067$ & $-0,324$ \\
\hline & & \multirow{2}{*}{$\begin{array}{l}95 \% \\
\text { Confidence Interval } \\
\text { for Exp(В)/Интервал } \\
\text { поверења за Ехр (В) }\end{array}$} & $\begin{array}{l}\text { Lower Bound/ } \\
\text { Инклинира нижем }\end{array}$ & 0,551 & 0,576 \\
\hline & & & $\begin{array}{l}\text { Upper Bound/ } \\
\text { Инклинира вишем }\end{array}$ & 1,587 & 0,908 \\
\hline & \multirow{3}{*}{\begin{tabular}{|l} 
worried \\
more than \\
normal / \\
забринут/а \\
више него \\
што је \\
нормално
\end{tabular}} & $\mathrm{B}$ & & 0,154 & 0,289 \\
\hline & & \multirow{2}{*}{$\begin{array}{l}95 \% \\
\text { Confidence Interval } \\
\text { for } \operatorname{Exp(B)/Интервал~} \\
\text { поверења за Ехр (В) }\end{array}$} & $\begin{array}{l}\text { Lower Bound/ } \\
\text { Инклинира нижем }\end{array}$ & 0,712 & 0,607 \\
\hline & & & $\begin{array}{l}\text { Upper Bound/ } \\
\text { Инклинира вишем }\end{array}$ & 1,910 & 0,924 \\
\hline & \multicolumn{3}{|c|}{ Extremely worried / Изузетно забринут/а } & $\begin{array}{c}1,00 \\
\text { (reference)/ } \\
\text { (референтна) }\end{array}$ & $\begin{array}{c}1,00 \\
\text { (reference)/ } \\
\text { (референтна) }\end{array}$ \\
\hline \multirow{8}{*}{$\begin{array}{l}\text { Anxiety/ } \\
\text { stress } \\
\text { level/Ниво } \\
\text { стреса/ } \\
\text { анксио- } \\
\text { зности }\end{array}$} & Нigh/Висок & $\begin{array}{l}95 \% \\
\text { Confidence Interval } \\
\text { for/Интервал } \\
\text { поверења за } \\
\text { Ехр (B) }\end{array}$ & $\begin{array}{l}\text { Upper Bound/ } \\
\text { Инклинира вишем }\end{array}$ & 2,509 & 1,321 \\
\hline & \multirow{3}{*}{$\begin{array}{l}\text { Medium/ } \\
\text { Средњи }\end{array}$} & $\mathrm{B}$ & & 0,132 & 0,129 \\
\hline & & \multirow{2}{*}{$\begin{array}{l}95 \% \\
\text { Confidence Interval } \\
\text { for } \operatorname{Exp(B)/Интервал~} \\
\text { поверења за } \operatorname{Exp~(В)~}\end{array}$} & $\begin{array}{l}\text { Lower Bound/ } \\
\text { Инклинира нижем }\end{array}$ & 0,721 & 0,924 \\
\hline & & & $\begin{array}{l}\text { Upper Bound/ } \\
\text { Инклинира вишем }\end{array}$ & 1,805 & 1,400 \\
\hline & \multirow{3}{*}{ Low/Низак } & $\mathrm{B}$ & & $-0,121$ & 0,165 \\
\hline & & \multirow{2}{*}{$\begin{array}{l}95 \% \\
\text { Confidence Interval } \\
\text { for } \operatorname{Exp(В)/Интервал~} \\
\text { поверења за Ехр (В) }\end{array}$} & $\begin{array}{l}\text { Lower Bound/ } \\
\text { Инклинира нижем }\end{array}$ & 0,539 & 0,945 \\
\hline & & & $\begin{array}{l}\text { Upper Bound/ } \\
\text { Инклинира вишем }\end{array}$ & 1,456 & 1,471 \\
\hline & \multicolumn{3}{|c|}{$\begin{array}{l}\text { No anxiety/stress/ } \\
\text { Без анксиозности/стреса }\end{array}$} & $\begin{array}{c}1,00 \\
\text { (reference)/ } \\
\text { (референтна) }\end{array}$ & $\begin{array}{c}1,00 \\
\text { (reference)/ } \\
\text { (референтна) }\end{array}$ \\
\hline
\end{tabular}

\begin{tabular}{|c|c|c|c|c|c|}
\hline \multirow{6}{*}{$\begin{array}{l}\text { Mode of } \\
\text { transmi- } \\
\text { ssion/Начин } \\
\text { трансми- } \\
\text { сије }\end{array}$} & \multirow{3}{*}{$\begin{array}{l}\text { Droplets/ } \\
\text { Капљице }\end{array}$} & \multicolumn{2}{|l|}{ B } & \multirow{2}{*}{$\begin{array}{r}\mathbf{1 , 0 9 7} \\
1,553\end{array}$} & \multirow{2}{*}{$\begin{array}{l}\mathbf{0 , 4 7 4} \\
0,480\end{array}$} \\
\hline & & \multirow{2}{*}{$\begin{array}{l}95 \% \\
\text { Confidence Interval } \\
\text { for Exp(B)/ } \\
\text { Интервал поверења } \\
\text { за Ехр (В) }\end{array}$} & $\begin{array}{l}\text { Lower Bound/ } \\
\text { Инклинира нижем }\end{array}$ & & \\
\hline & & & $\begin{array}{l}\text { Upper Bound } \\
\text { Инклинира вишем }\end{array}$ & 5,775 & 0,807 \\
\hline & \multirow{3}{*}{$\begin{array}{l}\text { Direct } \\
\text { Contact/ } \\
\text { Директан } \\
\text { контакт }\end{array}$} & B & & 0,771 & 0,653 \\
\hline & & \multirow{2}{*}{$\begin{array}{l}95 \% \\
\text { Confidence Interval } \\
\text { for Exp(B)/ } \\
\text { Интервал поверења } \\
\text { за Ехр (В) }\end{array}$} & $\begin{array}{l}\text { Lower Bound/ } \\
\text { Инклинира нижем }\end{array}$ & 1,133 & 0,403 \\
\hline & & & $\begin{array}{l}\text { Upper Bound/ } \\
\text { Инклинира вишем }\end{array}$ & 4,126 & 0,672 \\
\hline
\end{tabular}

Note: Responses to questions regarding behaviour were "always and / usually vs often and / never". Data are adjusted odds ratio ( $95 \%$ confidence level interval) unless otherwise noted, estimates in bold are significan at $\mathrm{p}<0.05$./ Напомена: Одговори на питања у вези са понашањем били су „увек и / обично“ наспрам "често и / никад“. Подаци представљају прилагођени показатељ вероватноће (интервал нивоа поверења од 95\%); осим уколико није другачије назначено, процене написане подебљаним словима су значајне при $\mathrm{p}<0,05$.

BACK

$\leftarrow$ НАЗАД

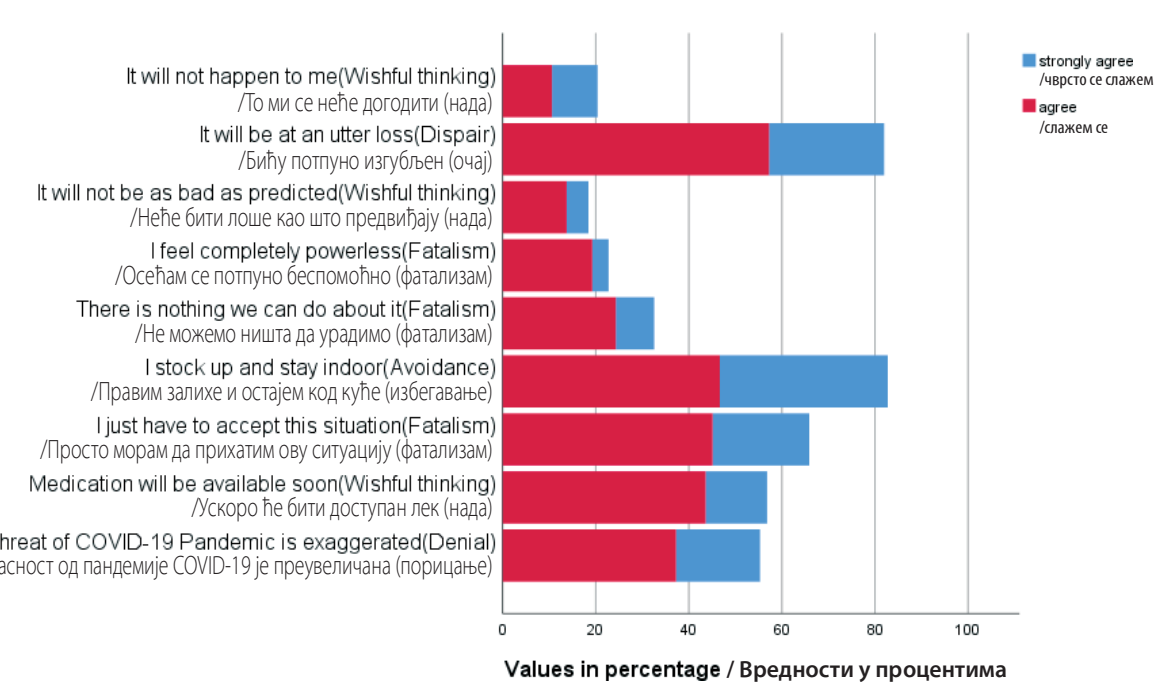

Figure 2: Maladaptive behavioural responses to COVID-19 pandemic / Слика 2: Маладаптивни бихевиорални одговори на пандемију COVID-19 
Table 5: Factors Affecting Adaptive responses: Social distancing behaviour $(\mathrm{N}=700)$

\begin{tabular}{|c|c|c|c|c|c|}
\hline \multicolumn{4}{|c|}{ Personal Demographic Variable } & \multirow{2}{*}{$\begin{array}{l}\begin{array}{c}\text { Avoid going to } \\
\text { family functions } \\
\text { and gathering }\end{array} \\
0,12\end{array}$} & \multirow{2}{*}{$\begin{array}{c}\begin{array}{c}\text { Avoid using } \\
\text { Public transport } \\
\text { including taxis }\end{array} \\
\mathbf{0 , 1 4}\end{array}$} \\
\hline \multirow{4}{*}{ Gender } & \multirow[t]{3}{*}{ MALE } & \multicolumn{2}{|l|}{ B } & & \\
\hline & & \multirow{2}{*}{$\begin{array}{l}95 \% \\
\text { Confidence Interval } \\
\text { for } \operatorname{Exp}(\mathrm{B})\end{array}$} & Lower Bound & 0,65 & 0,72 \\
\hline & & & Upper Bound & 1,20 & 1,03 \\
\hline & \multicolumn{3}{|l|}{ Female } & 1,00 (reference) & 1,00 (reference) \\
\hline \multirow{13}{*}{ Age Group } & \multirow[t]{3}{*}{$18-24$} & \multicolumn{2}{|l|}{ B } & 1,13 & 0,51 \\
\hline & & \multirow{2}{*}{$\begin{array}{l}95 \% \\
\text { Confidence Interval } \\
\text { for } \operatorname{Exp(B)}\end{array}$} & Lower Bound & 1,42 & 1,19 \\
\hline & & & Upper Bound & 6,76 & 2,35 \\
\hline & \multirow[t]{3}{*}{$25-34$} & \multicolumn{2}{|l|}{ B } & 0,95 & 0,63 \\
\hline & & \multirow{2}{*}{$\begin{array}{l}95 \% \\
\text { Confidence Interval } \\
\text { for } \operatorname{Exp}(\mathrm{B})\end{array}$} & Lower Bound & 1,21 & 1,39 \\
\hline & & & Upper Bound & 5,50 & 2,55 \\
\hline & \multirow[t]{3}{*}{$35-44$} & \multicolumn{2}{|l|}{ B } & 0,89 & 0,46 \\
\hline & & \multirow{2}{*}{$\begin{array}{l}95 \% \\
\text { Confidence Interval } \\
\text { for } \operatorname{Exp(B)}\end{array}$} & Lower Bound & 1,12 & 1,14 \\
\hline & & & Upper Bound & 5,31 & 2,19 \\
\hline & \multirow[t]{3}{*}{$45-54$} & \multicolumn{2}{|c|}{ B } & 0,91 & 0,49 \\
\hline & & \multirow{2}{*}{$\begin{array}{l}95 \% \\
\text { Confidence Interval } \\
\text { for Exp(B) }\end{array}$} & Lower Bound & 1,04 & 1,08 \\
\hline & & & Upper Bound & 5,96 & 2,45 \\
\hline & \multicolumn{3}{|c|}{ Above 55} & 1,00 (reference) & 1,00 (reference) \\
\hline \multirow{10}{*}{ Education } & \multirow{3}{*}{$\begin{array}{l}\text { Gradua- } \\
\text { tion }\end{array}$} & \multicolumn{2}{|l|}{ B } & 15,48 & 0,87 \\
\hline & & \multirow{2}{*}{$\begin{array}{l}95 \% \\
\text { Confidence Interval } \\
\text { for } \operatorname{Exp(B)}\end{array}$} & Lower Bound & 0,24 & 0,28 \\
\hline & & & Upper Bound & 1,13 & 0,62 \\
\hline & \multirow{3}{*}{$\begin{array}{l}\text { Post Gra } \\
\text { duation }\end{array}$} & \multicolumn{2}{|l|}{ B } & 15,77 & 0,54 \\
\hline & & \multirow{2}{*}{$\begin{array}{l}95 \% \\
\text { Confidence Interval } \\
\text { for } \operatorname{Exp(B)}\end{array}$} & Lower Bound & 0,36 & 0,42 \\
\hline & & & Upper Bound & 1,36 & 0,81 \\
\hline & \multirow{3}{*}{$\begin{array}{l}\text { Docto- } \\
\text { rate }\end{array}$} & \multicolumn{2}{|l|}{ B } & 15,87 & 1,03 \\
\hline & & \multirow{2}{*}{$\begin{array}{l}95 \% \\
\text { Confidence Interval } \\
\text { for } \operatorname{Exp(B)}\end{array}$} & Lower Bound & 0,65 & 0,20 \\
\hline & & & Upper Bound & 1,34 & 0,64 \\
\hline & Below G & duation & & 1,00 (reference) & 1,00 (reference) \\
\hline
\end{tabular}

\begin{tabular}{|c|c|c|c|}
\hline $\begin{array}{l}\text { Avoid going to } \\
\text { religious places }\end{array}$ & $\begin{array}{l}\text { Avoid going to } \\
\text { workplaces }\end{array}$ & $\begin{array}{l}\text { Are you going out for pur- } \\
\text { chasing essential items, if yes } \\
\text { answer next question }\end{array}$ & $\begin{array}{l}\text { Maintaining social distan- } \\
\text { cing while going out for } \\
\text { purchase of essential items }\end{array}$ \\
\hline 0,17 & 0,27 & 0,21 & 0,18 \\
\hline 0,80 & 1,06 & 0,68 & 0,66 \\
\hline 1,25 & 1,61 & 1,46 & 1,06 \\
\hline 1,00 (reference) & 1,00 (reference) & 1,00 (reference) & 1,00 (reference) \\
\hline$-0,27$ & $-0,21$ & $-0,59$ & 0,03 \\
\hline 0,52 & 0,57 & 0,30 & 0,70 \\
\hline 1,12 & 1,14 & 1,03 & 1,52 \\
\hline$-0,26$ & $-0,14$ & $-0,20$ & $-0,07$ \\
\hline 0,54 & 0,64 & 0,48 & 0,66 \\
\hline 1,09 & 1,18 & 1,39 & 1,33 \\
\hline$-0,36$ & 0,01 & $-0,83$ & $-0,12$ \\
\hline 0,48 & 0,74 & 0,24 & 0,61 \\
\hline 1,02 & 1,38 & 0,80 & 1,29 \\
\hline 0,07 & $-0,01$ & $-0,75$ & $-0,30$ \\
\hline 0,68 & 0,65 & 0,20 & 0,43 \\
\hline 1,69 & 1,51 & 1,10 & 1,27 \\
\hline 1,00 (reference) & 1,00 (reference) & 1,00 (reference) & 1,00 (reference) \\
\hline$-0,09$ & 0,17 & 0,10 & $-0,60$ \\
\hline 0,55 & 0,71 & 0,47 & 0,33 \\
\hline 1,52 & 1,98 & 2,60 & 0,90 \\
\hline 0,05 & 0,11 & $-0,52$ & 0,58 \\
\hline 0,62 & 0,70 & 0,27 & 0,37 \\
\hline 1,47 & 1,76 & 1,28 & 0,85 \\
\hline 0,02 & 0,53 & $-0,46$ & 0,82 \\
\hline 0,52 & 0,92 & 0,19 & 0,21 \\
\hline 2,02 & 3,13 & 2,07 & 0,90 \\
\hline nce) & 1,00 (reference) & 1,00 (reference) & 1.00 (reference) \\
\hline
\end{tabular}




\begin{tabular}{|c|c|c|c|c|c|}
\hline \multirow{10}{*}{$\begin{array}{l}\text { Self Health } \\
\text { Status }\end{array}$} & \multirow[t]{3}{*}{ Poor } & \multicolumn{2}{|l|}{ B } & $-0,30$ & 0,91 \\
\hline & & \multirow{2}{*}{$\begin{array}{l}95 \% \\
\text { Confidence Interval } \\
\text { for } \operatorname{Exp}(\mathrm{B})\end{array}$} & Lower Bound & 0,23 & 1,30 \\
\hline & & & Upper Bound & 2,36 & 4,75 \\
\hline & \multirow[t]{3}{*}{ Fair } & \multicolumn{2}{|l|}{ B } & $-0,78$ & 0,46 \\
\hline & & \multirow{2}{*}{$\begin{array}{l}95 \% \\
\text { Confidence Interval } \\
\text { for } \operatorname{Exp(B)}\end{array}$} & Lower Bound & 0,22 & 0,89 \\
\hline & & & Upper Bound & 0,98 & 2,82 \\
\hline & \multirow[t]{3}{*}{ Good } & \multicolumn{2}{|c|}{ B } & $-0,41$ & 0,41 \\
\hline & & \multirow{2}{*}{$\begin{array}{l}95 \% \\
\text { Confidence Interval } \\
\text { for } \operatorname{Exp}(\mathrm{B})\end{array}$} & Lower Bound & 0,38 & 0,91 \\
\hline & & & Upper Bound & 1,15 & 2,48 \\
\hline & \multicolumn{3}{|c|}{ Excellent } & 1,00 (reference) & 1,00 (reference) \\
\hline \multirow{10}{*}{$\begin{array}{l}\text { Anxiety/stress } \\
\text { level// }\end{array}$} & \multirow[t]{3}{*}{ High } & \multicolumn{2}{|l|}{ B } & 0,43 & 0,47 \\
\hline & & \multirow{2}{*}{$\begin{array}{l}95 \% \\
\text { Confidence Interval } \\
\text { for Exp(B) }\end{array}$} & Lower Bound & 0,86 & 0,44 \\
\hline & & & Upper Bound & 2,77 & 0,90 \\
\hline & \multirow[t]{3}{*}{ Medium } & \multicolumn{2}{|l|}{ B } & 0,33 & 0,21 \\
\hline & & \multirow{2}{*}{$\begin{array}{l}95 \% \\
\text { Confidence Interval } \\
\text { for } \operatorname{Exp}(\mathrm{B})\end{array}$} & Lower Bound & 0,93 & 0,65 \\
\hline & & & Upper Bound & 2,08 & 1,01 \\
\hline & \multirow[t]{3}{*}{ Low } & \multicolumn{2}{|l|}{$B$} & 0,27 & 0,35 \\
\hline & & \multirow{2}{*}{$\begin{array}{l}95 \% \\
\text { Confidence Interval } \\
\text { for Exp(B) }\end{array}$} & Lower Bound & 0,83 & 0,56 \\
\hline & & & Upper Bound & 2,08 & 0,90 \\
\hline & \multicolumn{3}{|c|}{ No anxiety/stress } & 1,00 (reference) & 1,00 (reference) \\
\hline \multirow{10}{*}{$\begin{array}{l}\text { Worried if } \\
\text { have } \\
\text { COVID-19 }\end{array}$} & \multirow{3}{*}{$\begin{array}{l}\text { Not at all } \\
\text { worried }\end{array}$} & \multicolumn{2}{|l|}{ B } & 0,23 & 0,11 \\
\hline & & \multirow{2}{*}{$\begin{array}{l}95 \% \\
\text { Confidence Interval } \\
\text { for } \operatorname{Exp}(\mathrm{B})\end{array}$} & Lower Bound & 0,68 & 0,66 \\
\hline & & & Upper Bound & 2,33 & 1,21 \\
\hline & \multirow{3}{*}{$\begin{array}{c}\text { Much } \\
\text { less wor- } \\
\text { ried than } \\
\text { normal }\end{array}$} & \multicolumn{2}{|l|}{ B } & 0,56 & 0,01 \\
\hline & & \multirow{2}{*}{$\begin{array}{l}95 \% \\
\text { Confidence Interval } \\
\text { for Exp(B) }\end{array}$} & Lower Bound & 1,04 & 0,79 \\
\hline & & & Upper Bound & 2,92 & 1,30 \\
\hline & \multirow{3}{*}{$\begin{array}{l}\text { Worried } \\
\text { more } \\
\text { than } \\
\text { normal }\end{array}$} & \multicolumn{2}{|l|}{ B } & 0,54 & 0,28 \\
\hline & & $95 \%$ & Lower Bound & 1,04 & 0,59 \\
\hline & & for $\operatorname{Exp}(B)$ & Upper Bound & 2,85 & 0,96 \\
\hline & Extremely & worried & & 1,00 (reference) & 1,00 (reference) \\
\hline
\end{tabular}

Note: Responses to questions regarding behaviour were "always and / usually vs often and / never". Data are adjusted odds ratio ( $95 \%$ confidence level interval) unless otherwise noted, estimates in bold are significant at $\mathrm{p}<0.05$.

\begin{tabular}{|c|c|c|c|}
\hline$-0,37$ & 0,51 & 1,86 & $-1,16$ \\
\hline 0,20 & 0,80 & 1,65 & 0,06 \\
\hline 2,46 & 3,45 & 25,02 & 1,65 \\
\hline 0,77 & $-0,17$ & 0,26 & 0,75 \\
\hline 1,10 & 0,51 & 0,45 & 1,20 \\
\hline 4,22 & 1,41 & 3,67 & 3,77 \\
\hline 0,51 & 0,10 & 0,60 & 0,04 \\
\hline 0,91 & 0,73 & 0,80 & 0,63 \\
\hline 3,05 & 1,65 & 4,18 & 1,73 \\
\hline 1,00 (reference) & 1,00 (reference) & 1,00 (reference) & 1,00 (reference) \\
\hline 0,19 & $-0,33$ & 0,61 & 0,20 \\
\hline 0,78 & 0,48 & 0,91 & 0,80 \\
\hline 1,86 & 1,07 & 3,71 & 1,89 \\
\hline 0,12 & $-0,25$ & $-0,30$ & 0,05 \\
\hline 0,85 & 0,60 & 0,44 & 0,78 \\
\hline 1,50 & 1,01 & 1,24 & 1,42 \\
\hline$-0,05$ & $-0,28$ & 0,23 & $-0,27$ \\
\hline 0,68 & 0,57 & 0,74 & 0,53 \\
\hline 1,32 & 1,00 & 2,14 & 1,09 \\
\hline 1,00 (reference) & 1,00 (reference) & 1,00 (reference) & 1,00 (reference) \\
\hline 0,31 & $-0,02$ & $-0,62$ & $-0,34$ \\
\hline 0,92 & 0,69 & 0,27 & 0,48 \\
\hline 2,00 & 1,40 & 1,07 & 1,06 \\
\hline$-0,13$ & $-0,05$ & $-0,72$ & $-0,31$ \\
\hline 0,62 & 0,70 & 0,27 & 0,52 \\
\hline 1,26 & 1,29 & 0,86 & 1,02 \\
\hline 0,18 & 0,01 & $-0,10$ & 0,46 \\
\hline 0,86 & 0,75 & 0,54 & 0,46 \\
\hline 1,67 & 1,35 & 1,53 & 0,88 \\
\hline 1,00 (reference) & 1,00 (reference) & 1,00 (reference) & 1,00 (reference) \\
\hline
\end{tabular}


Табела 5: Фактори који утичу на адаптивне одговоре: понашање социјалног дистанцирања $(\mathrm{N}=700)$

\begin{tabular}{|c|c|c|c|c|c|}
\hline & \multicolumn{3}{|c|}{ Личне демографске варијабле } & $\begin{array}{c}\text { Избегава } \\
\text { породична } \\
\text { славља и }\end{array}$ & $\begin{array}{c}\text { Избегава } \\
\text { јавни превоз, } \\
\text { укључујући и }\end{array}$ \\
\hline \multirow{4}{*}{ Пол } & \multirow[t]{3}{*}{ МУШКИ } & \multicolumn{2}{|l|}{ B } & 0,12 & 0,14 \\
\hline & & \multirow{2}{*}{$\begin{array}{l}95 \% \\
\text { Интервал пове- } \\
\text { рења за Ехр (В) }\end{array}$} & Инклинира нижем & 0,65 & 0,72 \\
\hline & & & Инклинира вишем & 1,20 & 1,03 \\
\hline & \multicolumn{3}{|l|}{ Женски } & 1,00 (референтна) & 1,00 (референтна) \\
\hline \multirow{13}{*}{$\begin{array}{l}\text { Старосна } \\
\text { група }\end{array}$} & \multirow[t]{3}{*}{$18-24$} & \multicolumn{2}{|l|}{ B } & 1,13 & 0,51 \\
\hline & & \multirow{2}{*}{$\begin{array}{l}95 \% \\
\text { Интервал пове- } \\
\text { рења за Ехр (В) }\end{array}$} & Инклинира нижем & 1,42 & 1,19 \\
\hline & & & Инклинира вишем & 6,76 & 2,35 \\
\hline & \multirow[t]{3}{*}{$25-34$} & \multicolumn{2}{|l|}{$\mathrm{B}$} & 0,95 & 0,63 \\
\hline & & \multirow{2}{*}{$\begin{array}{l}95 \% \\
\text { Интервал пове- } \\
\text { рења за Ехр (В) }\end{array}$} & Инклинира нижем & 1,21 & 1,39 \\
\hline & & & Инклинира вишем & 5,50 & 2,55 \\
\hline & \multirow[t]{3}{*}{ 35-44 } & \multicolumn{2}{|l|}{ B } & 0,89 & 0,46 \\
\hline & & \multirow{2}{*}{$\begin{array}{l}95 \% \\
\text { Интервал пове- } \\
\text { рења за Ехр (В) }\end{array}$} & Инклинира нижем & 1,12 & 1,14 \\
\hline & & & Инклинира вишем & 5,31 & 2,19 \\
\hline & \multirow[t]{3}{*}{$45-54$} & \multicolumn{2}{|l|}{ B } & 0,91 & 0,49 \\
\hline & & \multirow{2}{*}{$\begin{array}{l}\text { 95\% } \\
\text { Интервал пове- } \\
\text { рења за Ехр (В) }\end{array}$} & Инклинира нижем & 1,04 & 1,08 \\
\hline & & & Инклинира вишем & 5,96 & 2,45 \\
\hline & \multicolumn{3}{|l|}{ Преко 55} & 1,00 (референтна) & 1,00 (референтна) \\
\hline \multirow{10}{*}{$\begin{array}{l}\text { Степен } \\
\text { образовања }\end{array}$} & \multirow{3}{*}{$\begin{array}{l}\text { Факул- } \\
\text { тетска } \\
\text { диплома }\end{array}$} & \multicolumn{2}{|l|}{ B } & 15,48 & 0,87 \\
\hline & & \multirow{2}{*}{$\begin{array}{l}\text { 95\% } \\
\text { Интервал пове- } \\
\text { рења за Ехр (В) } \\
\end{array}$} & Инклинира нижем & 0,24 & 0,28 \\
\hline & & & Инклинира вишем & 1,13 & 0,62 \\
\hline & \multirow{3}{*}{$\begin{array}{l}\text { Маги- } \\
\text { стар }\end{array}$} & \multicolumn{2}{|l|}{ B } & 15,77 & 0,54 \\
\hline & & \multirow{2}{*}{$\begin{array}{l}\text { 95\% } \\
\text { Интервал пове- } \\
\text { рења за Ехр (В) }\end{array}$} & Инклинира нижем & 0,36 & 0,42 \\
\hline & & & Инклинира вишем & 1,36 & 0,81 \\
\hline & \multirow{3}{*}{$\begin{array}{l}\text { Доктор } \\
\text { наука }\end{array}$} & \multicolumn{2}{|l|}{ B } & 15,87 & 1,03 \\
\hline & & \multirow{2}{*}{$\begin{array}{l}95 \% \\
\text { Интервал пове- } \\
\text { рења за Ехр (В) }\end{array}$} & Инклинира нижем & 0,65 & 0,20 \\
\hline & & & Инклинира вишем & 1,34 & 0,64 \\
\hline & \multicolumn{3}{|c|}{ Средња школа } & 1,00 (референтна) & 1,00 (референтна) \\
\hline
\end{tabular}

\begin{tabular}{|c|c|c|c|}
\hline $\begin{array}{c}\text { Избегава верске } \\
\text { објекте }\end{array}$ & $\begin{array}{c}\text { Избегава } \\
\text { одлазак на } \\
\text { радно место }\end{array}$ & $\begin{array}{c}\text { Излазите ли у набавку } \\
\text { основних намирница? Ако је } \\
\text { одговор потврдан, одговорите } \\
\text { на следеће питање }\end{array}$ & $\begin{array}{l}\text { Држање социјалне } \\
\text { дистанце приликом } \\
\text { одласка у набавку } \\
\text { основних намирница }\end{array}$ \\
\hline 0,17 & 0,27 & 0,21 & 0,18 \\
\hline 0,80 & 1,06 & 0,68 & 0,66 \\
\hline 1,25 & 1,61 & 1,46 & 1,06 \\
\hline 1,00 (референтна) & 1,00 (референтна) & 1,00 (референтна) & 1,00 (референтна) \\
\hline$-0,27$ & $-0,21$ & $-0,59$ & 0,03 \\
\hline 0,52 & 0,57 & 0,30 & 0,70 \\
\hline 1,12 & 1,14 & 1,03 & 1,52 \\
\hline$-0,26$ & $-0,14$ & $-0,20$ & $-0,07$ \\
\hline 0,54 & 0,64 & 0,48 & 0,66 \\
\hline 1,09 & 1,18 & 1,39 & 1,33 \\
\hline$-0,36$ & 0,01 & $-0,83$ & $-0,12$ \\
\hline 0,48 & 0,74 & 0,24 & 0,61 \\
\hline 1,02 & 1,38 & 0,80 & 1,29 \\
\hline 0,07 & $-0,01$ & $-0,75$ & $-0,30$ \\
\hline 0,68 & 0,65 & 0,20 & 0,43 \\
\hline 1,69 & 1,51 & 1,10 & 1,27 \\
\hline 1,00 (референтна) & 1,00 (референтна) & 1,00 (референтна) & 1,00 (референтна) \\
\hline$-0,09$ & 0,17 & 0,10 & $-0,60$ \\
\hline 0,55 & 0,71 & 0,47 & 0,33 \\
\hline 1,52 & 1,98 & 2,60 & 0,90 \\
\hline 0,05 & 0,11 & $-0,52$ & 0,58 \\
\hline 0,62 & 0,70 & 0,27 & 0,37 \\
\hline 1,47 & 1,76 & 1,28 & 0,85 \\
\hline 0,02 & 0,53 & $-0,46$ & 0,82 \\
\hline 0,52 & 0,92 & 0,19 & 0,21 \\
\hline 2,02 & 3,13 & 2,07 & 0,90 \\
\hline 1,00 (референтна) & 1,00 (референтна) & 1,00 (референтна) & 1,00 (референтна) \\
\hline
\end{tabular}




\begin{tabular}{|c|c|c|c|c|c|}
\hline \multirow{10}{*}{$\begin{array}{l}\text { Лична оцена } \\
\text { здравственог } \\
\text { стања }\end{array}$} & \multirow[t]{3}{*}{ Лоше } & \multicolumn{2}{|l|}{ B } & $-0,30$ & 0,91 \\
\hline & & \multirow{2}{*}{$\begin{array}{l}95 \% \\
\text { Интервал пове- } \\
\text { рења за Ехр (В) } \\
\end{array}$} & Инклинира нижем & 0,23 & 1,30 \\
\hline & & & Инклинира вишем & 2,36 & 4,75 \\
\hline & \multirow{3}{*}{$\begin{array}{l}\text { При- } \\
\text { хватљи- } \\
\text { во }\end{array}$} & \multicolumn{2}{|l|}{ B } & $-0,78$ & 0,46 \\
\hline & & \multirow{2}{*}{\begin{tabular}{|l}
$95 \%$ \\
Интервал пове- \\
рења за Ехр (В)
\end{tabular}} & Инклинира нижем & 0,22 & 0,89 \\
\hline & & & Инклинира вишем & 0,98 & 2,82 \\
\hline & \multirow[t]{3}{*}{ Добро } & \multicolumn{2}{|l|}{ B } & $-0,41$ & 0,41 \\
\hline & & \multirow{2}{*}{$\begin{array}{l}\text { 95\% } \\
\text { Интервал пове- } \\
\text { рења за Ехр (В) }\end{array}$} & Инклинира нижем & 0,38 & 0,91 \\
\hline & & & Инклинира вишем & 1,15 & 2,48 \\
\hline & \multicolumn{3}{|c|}{ Одлично } & 1,00 (референтна) & 1,00 (референтна) \\
\hline \multirow{10}{*}{$\begin{array}{l}\text { Ниво стреса/ } \\
\text { анксиозности }\end{array}$} & \multirow[t]{3}{*}{ Висок } & \multicolumn{2}{|l|}{ B } & 0,43 & 0,47 \\
\hline & & \multirow{2}{*}{\begin{tabular}{|l}
$95 \%$ \\
Интервал пове- \\
рења за Ехр (В) \\
\end{tabular}} & Инклинира нижем & 0,86 & 0,44 \\
\hline & & & Инклинира вишем & 2,77 & 0,90 \\
\hline & \multirow{3}{*}{ Средњи } & \multicolumn{2}{|l|}{ B } & 0,33 & 0,21 \\
\hline & & \multirow{2}{*}{$\begin{array}{l}95 \% \\
\text { Интервал пове- } \\
\text { рења за Ехр (В) }\end{array}$} & Инклинира нижем & 0,93 & 0,65 \\
\hline & & & Инклинира вишем & 2,08 & 1,01 \\
\hline & \multirow[t]{3}{*}{ Низак } & \multicolumn{2}{|l|}{ B } & 0,27 & 0,35 \\
\hline & & \multirow{2}{*}{\begin{tabular}{|l}
$95 \%$ \\
Интервал пове- \\
рења за Ехр (В)
\end{tabular}} & Инклинира нижем & 0,83 & 0,56 \\
\hline & & & Инклинира вишем & 2,08 & 0,90 \\
\hline & \multicolumn{3}{|c|}{ Без анксиозности/стреса } & 1,00 (референтна) & 1,00 (референтна) \\
\hline \multirow{10}{*}{$\begin{array}{l}\text { Забринут/а } \\
\text { да ли има } \\
\text { COVID-19 }\end{array}$} & \multirow{3}{*}{$\begin{array}{c}\text { Уопште } \\
\text { није } \\
\text { забри- } \\
\text { нут/а }\end{array}$} & \multicolumn{2}{|l|}{ B } & 0,23 & 0,11 \\
\hline & & \multirow{2}{*}{$\begin{array}{l}95 \% \\
\text { Интервал пове- } \\
\text { рења за Ехр (В) }\end{array}$} & Инклинира нижем & 0,68 & 0,66 \\
\hline & & & Инклинира вишем & 2,33 & 1,21 \\
\hline & \multirow{3}{*}{\begin{tabular}{|c|} 
Много \\
мање \\
забри- \\
нут/а \\
него што \\
је нор- \\
мално \\
\end{tabular}} & \multicolumn{2}{|l|}{ B } & 0,56 & 0,01 \\
\hline & & \multirow{2}{*}{$\begin{array}{l}\text { 95\% } \\
\text { Интервал пове- } \\
\text { рења за Ехр (В) }\end{array}$} & Инклинира нижем & 1,04 & 0,79 \\
\hline & & & Инклинира вишем & 2,92 & 1,30 \\
\hline & \multirow{3}{*}{$\begin{array}{c}\text { Забринут } \\
\text { а више } \\
\text { него што } \\
\text { је нор- } \\
\text { мално } \\
\end{array}$} & \multicolumn{2}{|l|}{ B } & 0,54 & 0,28 \\
\hline & & & Инклинира нижем & 1,04 & 0,59 \\
\hline & & рења за Еxp (B) & Инклинира вишем & 2,85 & 0,96 \\
\hline & Изузетно & забринут/а & & 1,00 (референтна) & 1,00 (референтна) \\
\hline
\end{tabular}

\begin{tabular}{|c|c|c|c|}
\hline$-0,37$ & 0,51 & 1,86 & $-1,16$ \\
\hline 0,20 & 0,80 & 1,65 & 0,06 \\
\hline 2,46 & 3,45 & 25,02 & 1,65 \\
\hline 0,77 & $-0,17$ & 0,26 & 0,75 \\
\hline 1,10 & 0,51 & 0,45 & 1,20 \\
\hline 4,22 & 1,41 & 3,67 & 3,77 \\
\hline 0,51 & 0,10 & 0,60 & 0,04 \\
\hline 0,91 & 0,73 & 0,80 & 0,63 \\
\hline 3,05 & 1,65 & 4,18 & 1,73 \\
\hline 1,00 (референтна) & 1,00 (референтна) & 1,00 (референтна) & 1,00 (референтна) \\
\hline 0,19 & $-0,33$ & 0,61 & 0,20 \\
\hline 0,78 & 0,48 & 0,91 & 0,80 \\
\hline 1,86 & 1,07 & 3,71 & 1,89 \\
\hline 0,12 & $-0,25$ & $-0,30$ & 0,05 \\
\hline 0,85 & 0,60 & 0,44 & 0,78 \\
\hline 1,50 & 1,01 & 1,24 & 1,42 \\
\hline$-0,05$ & $-0,28$ & 0,23 & $-0,27$ \\
\hline 0,68 & 0,57 & 0,74 & 0,53 \\
\hline 1,32 & 1,00 & 2,14 & 1,09 \\
\hline 1,00 (референтна) & 1,00 (референтна) & 1,00 (референтна) & 1,00 (референтна) \\
\hline 0,31 & $-0,02$ & $-0,62$ & $-0,34$ \\
\hline 0,92 & 0,69 & 0,27 & 0,48 \\
\hline 2,00 & 1,40 & 1,07 & 1,06 \\
\hline$-0,13$ & $-0,05$ & $-0,72$ & $-0,31$ \\
\hline 0,62 & 0,70 & 0,27 & 0,52 \\
\hline 1,26 & 1,29 & 0,86 & 1,02 \\
\hline 0,18 & 0,01 & $-0,10$ & 0,46 \\
\hline 0,86 & 0,75 & 0,54 & 0,46 \\
\hline 1,67 & 1,35 & 1,53 & 0,88 \\
\hline 1,00 (референтна) & 1,00 (референтна) & 1,00 (референтна) & 1,00 (референтна) \\
\hline
\end{tabular}

Напомена: Одговори на питања у вези са понашањем били су „увек и / обично“ наспрам „често и /

никад“. Подаци представљају прилагођени показатељ вероватноће (интервал нивоа поверења од

95\%); осим уколико није другачије назначено, процене написане подебљаним словима су значајне при $\mathrm{p}<0,05$. 


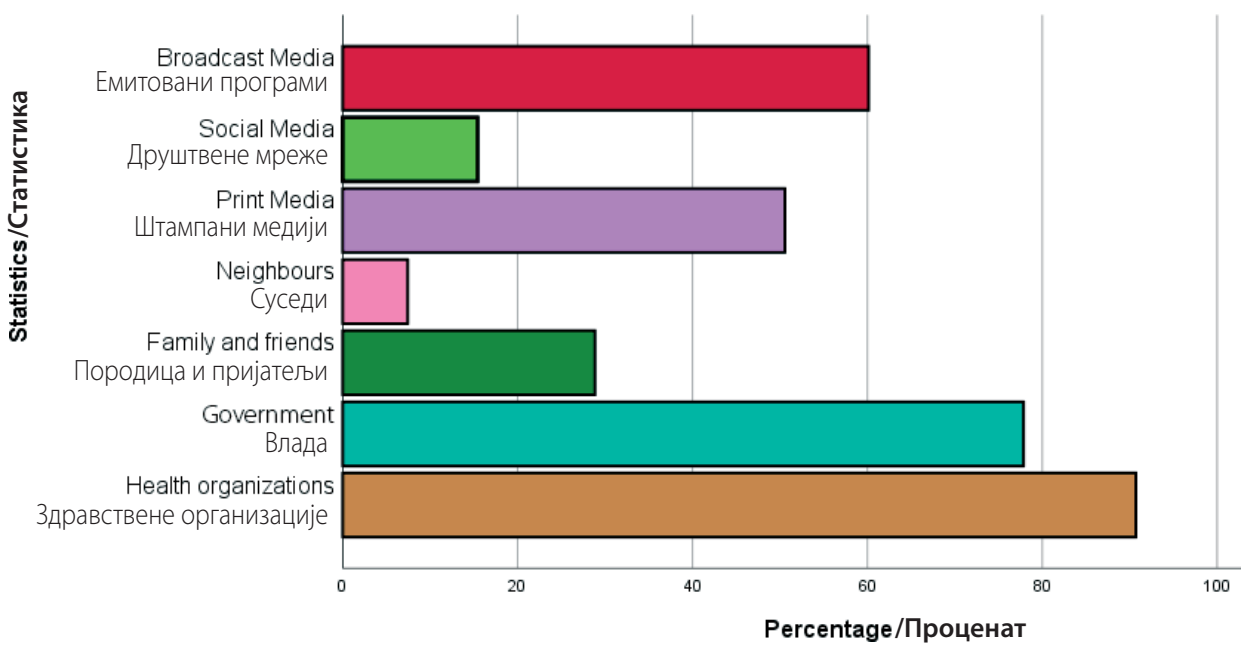

Figure 3: - Perceived trustworthiness of information sources / Слика 3: - Перципирана поузданост извора информација

Which places pose the greater risk Која места носе већи ризик

The severity of the infection Озбиљност заразе

How the infection is transmitted Како се зараза преноси

How the infection is treated Како се зараза лечи

How an infection can be recognised Како се зараза може препознати

Which protective measure to take Које заштитне мере предузети

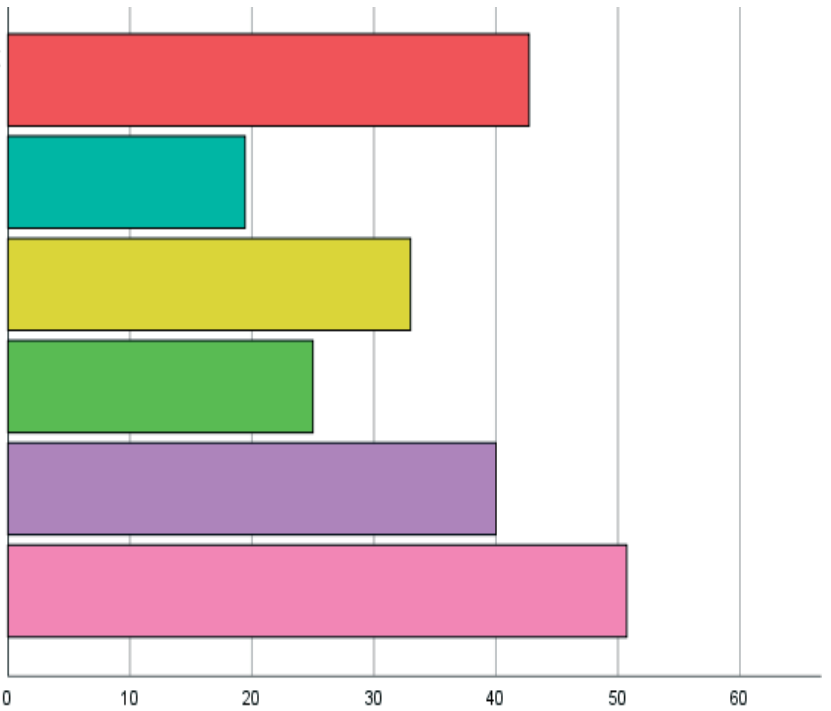

Percentage/Проценат

Figure 4: Perceived ufgancy of information / Слика 4: Перципирана хитност у објављивању информација 
Table 6: Variable description / Табела 6: Опис варијабли

\begin{tabular}{|c|c|}
\hline Variable/Варијабла & Indicators/Показатељи \\
\hline $\begin{array}{l}\text { SI (Self-isolate)/SI } \\
\text { (Самоизолација) }\end{array}$ & $\begin{array}{l}\text { You are advised by the government to isolate yourself at home be- } \\
\text { cause of exposure to large-scale infectious disease, do you think you } \\
\text { could do it?/Влада je препоручила да због изложености заразној } \\
\text { болести великих размера будете у кућној самоизолацији, } \\
\text { мислите ли да бисте то могли? }\end{array}$ \\
\hline $\begin{array}{l}\text { ATT (Attitude)/ } \\
\text { ATT (Став) }\end{array}$ & $\begin{array}{l}\text { Do you agree or disagree with the government's mandatory isola- } \\
\text { tion of infected people during a large-scale epidemic of an infec- } \\
\text { tious disease?/Слажете ли се са мером обавезне самоизолације } \\
\text { заражених особа, коју је наложила влада, током епидемије } \\
\text { заразне болести великих размера? }\end{array}$ \\
\hline $\begin{array}{c}\text { SN } \\
\text { (Subjective Norms)/ } \\
\text { SN (Субјективне } \\
\text { норме) }\end{array}$ & $\begin{array}{l}\text { If you will infected with a pandemic disease, would you let } \\
\text { your neighbours or colleagues know?/Ако бисте се заразили } \\
\text { пандемијском болешћу, да ли бисте о томе обавестили своје } \\
\text { суседе и колеге? } \\
\text { Do you show social acceptance to the people who recovered from } \\
\text { COVID-19?/Показујете ли друштвено прихватање особа које су се } \\
\text { опоравиле од инфекције COVID-19? }\end{array}$ \\
\hline $\begin{array}{c}\text { PBC } \\
\text { (Perceived behavioural } \\
\text { control)/ } \\
\text { РВС (Перципирана } \\
\text { контрола понашања) }\end{array}$ & $\begin{array}{l}\text { Do you think that a large-scale infectious disease would have a se- } \\
\text { rious impact on you or your family, Do you have confidence that } \\
\text { you can protect yourself and your family if a large scale infectious } \\
\text { disease occurs, Worry if have COVID-19?/Да ли сматрате да би } \\
\text { заразна болест великих размера могла озбиљно да се одрази } \\
\text { на Вас и Вашу породицу? Јесте ли сигурни да можете заштитити } \\
\text { себе и своју породицу у случају појаве заразне болести великих } \\
\text { размера? Јесте ли забринути да ли имате COVID-19? }\end{array}$ \\
\hline
\end{tabular}




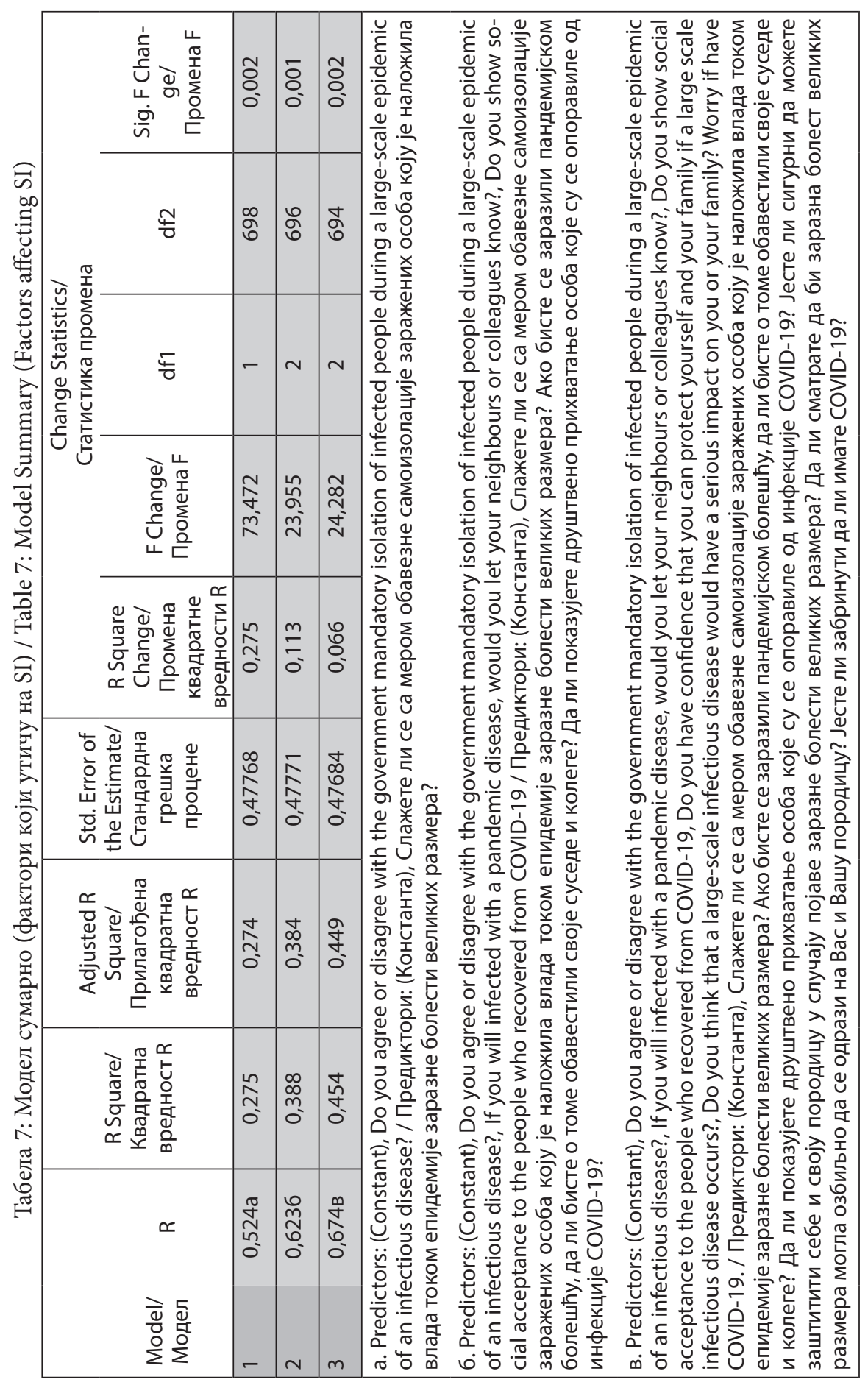

